\title{
Forecasting banking crises with dynamic panel probit models
}

\section{Working Papers 2016}
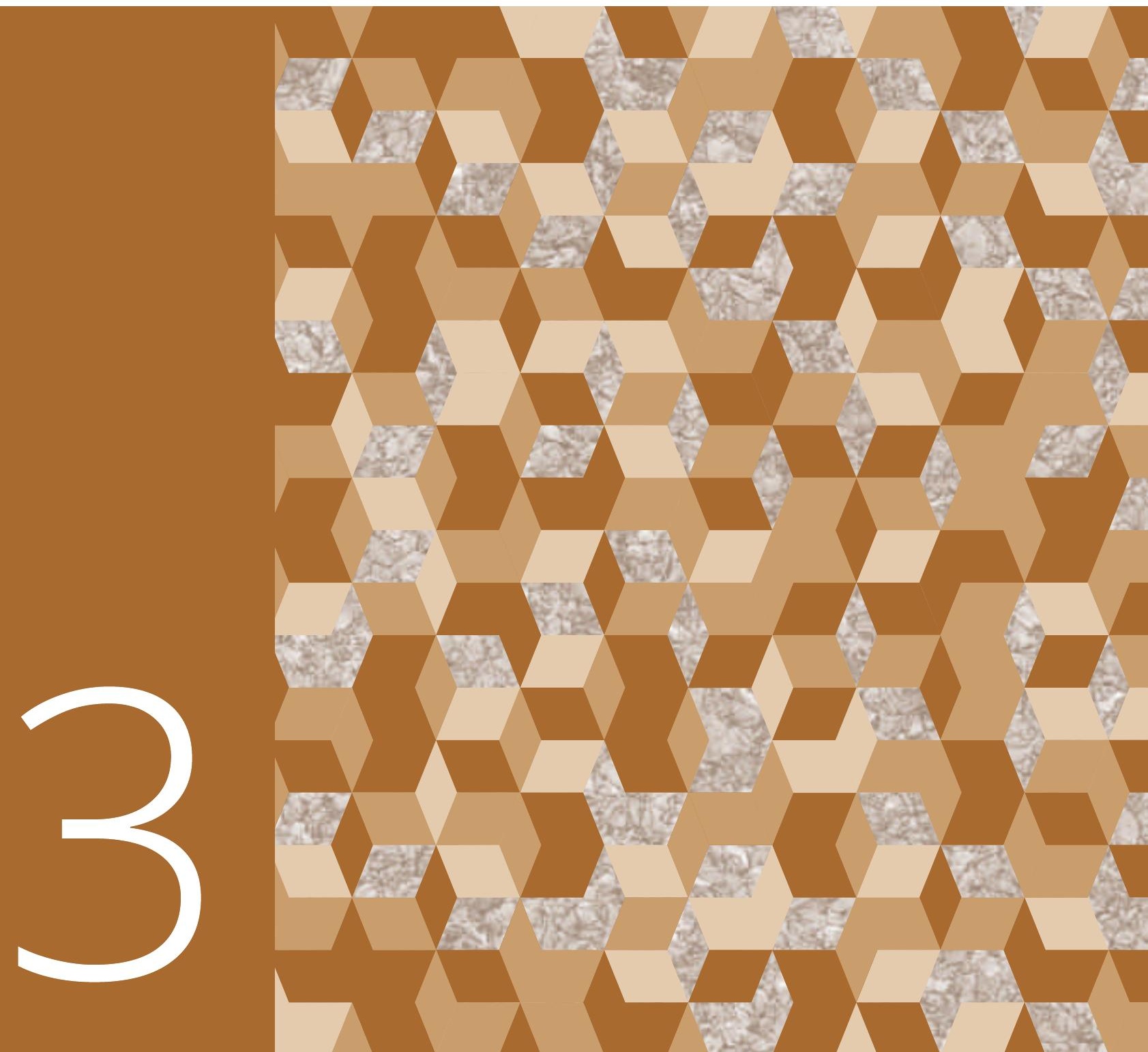



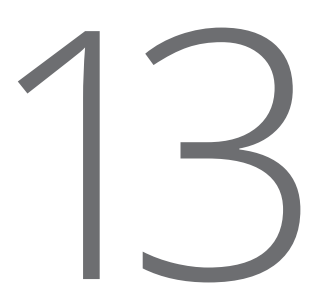

\section{Forecasting banking crises with dynamic panel probit models}

\section{Working Papers 2016}

António Antunes | Diana Bonfim | Nuno Monteiro

Paulo M. M. Rodrigues

The analyses, opinions and findings of these papers represent the views of the authors, they are not necessarily those of the Banco de Portugal or the Eurosystem

Please address correspondence to

Banco de Portugal, Economics and Research Department

Av. Almirante Reis 71, 1150-012 Lisboa, Portugal

T+351213130000 | estudos@bportugal.pt

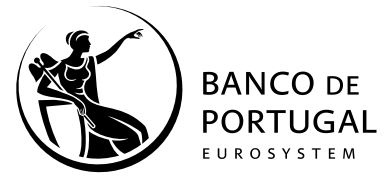

Lisbon, 2016 • www.bportugal.pt 
WORKING PAPERS | Lisbon 2016 • Banco de Portugal Av. Almirante Reis, 71 | 1150-012 Lisboa • www.bportugal.pt • Edition Economics and Research Department • ISBN 978-989-678-460-7 (online) • ISSN 2182-0422 (online) 


\title{
Forecasting banking crises with dynamic panel probit models
}

\author{
António Antunes \\ Banco de Portugal \\ NOVA School of Business and \\ Economics \\ Nuno Monteiro \\ Banco de Portugal
}

\author{
Diana Bonfim \\ Banco de Portugal
}

\author{
Paulo M. M. Rodrigues \\ Banco de Portugal \\ NOVA School of Business and \\ Economics
}

August 2016

\begin{abstract}
Banking crises are rare events, but when they occur their consequences are often dramatic. The aim of this paper is to contribute to the toolkit of early warning models available to policy makers by exploring the dynamics and non-linearities embedded in a panel dataset covering several countries over four decades (from 1970Q1 to 2010Q4). The in-sample and out-of-sample forecast performance of several dynamic probit models is evaluated, with the objective of developing a common vulnerability indicator with early warning properties. The results obtained show that adding dynamic components and exuberance indicators to the models substantially improves the ability to forecast banking crises.
\end{abstract}

JEL: C12, C22

Keywords: Banking crisis, binary data, dynamic probit models, early warning indicators.

Acknowledgements: We are grateful to participants of the ECB/MaRs Workshop on Early Warning Tools and Tools for Supporting Macroprudential Policies, PFN 2014, BdP Conference on Econometric Methods for Banking and Finance and a seminar at Banco de Portugal for insightful comments and suggestions. The analyses, opinions and findings of this article represent the views of the authors, which are not necessarily those of Banco de Portugal or the Eurosystem.

E-mail: aantunes@bportugal.pt; dbonfim@bportugal.pt; nmmonteiro@bportugal.pt; pmrodrigues@bportugal.pt 


\section{Introduction}

Predicting banking crises is certainly a difficult endeavour. On the one hand, it is econometrically very challenging to predict these rare events, which in many cases have different causes and consequences. On the other, even if accurately predicting an emerging banking crisis with some anticipation were feasible, policymakers would ideally be able to take all the necessary measures to avoid its materialization, which would then make the method fail.

The aim of this paper is to contribute to improve the early warning toolkit available to policymakers. Over the last decades, there have been many and diverse contributions to help identify the main drivers of financial crises and to aid policymakers in forecasting the next crisis. A large part of this literature focuses on currency crises, most notably in emerging market economies (Krugman 1979; Obstfeld 1986, Chang and Velasco 2001; Burnside et al. 2004). Often currency crises go hand in hand with banking crises, as noted by Kaminsky and Reinhart (1999). When a financial crisis is characterized by serious disruptions and losses in the banking system, the negative effects on the economy usually last longer and are more pronounced (Cecchetti et al. 2009 Jordà et al. 2011, 2013).

Although every crisis is different and unique (Reinhart and Rogoff 2011), we explore the commonalities of these rare events in a dataset of European systemic banking crises. Our main contribution relies on exploring the dynamics and exuberant behaviour in the time series of the dependent and independent variables, respectively. A wide range of methodologies has been used in the literature to forecast banking crises ${ }^{1}$ Demirgüç-Kunt and Detragiache (2005) and Davis and Woutersen (2008) have used a signal approach and a multivariate binary model, building upon the important contribution of Estrella and Hardouvelis (1991), who were among the first to show that binary models could be used successfully for forecasting purposes. Bussière and Fratzscher (2006) and Caggiano et al. (2014) used a multinomial logit approach, which allows for the distinction between more than two states (for instance, tranquil, crisis and post-crisis periods). To explore the contribution of a joint deterioration in

1. For a recent and comprehensive review of this literature see, for instance, Frankel and Saravelos (2012) and Kauko (2014). 
several variables, Duttagupta and Cashin (2011) use binary classification trees. More recently, Alessi and Detken (2011) use a related methodology to predict banking crises. These authors use a random forest method, which bootstraps and aggregates a multitude of decision trees.

We find that using a dynamic probit specification significantly contributes to enhance the forecast accuracy of early warning models. Exploring the dynamics intrinsic to the panel dataset allows us to substantially improve the forecasting power of the models, when compared to static binary models. This is true for both the in- and the out-of-sample exercises, when looking at a wide array of metrics to assess the performance of the model.

Despite the ever-growing literature on early warning tools and the variety of methodologies used, the dynamics embedded in the dependent variable have not been greatly explored. Falcetti and Tudela (2006) were perhaps the first authors to study the determinants of currency crises in emerging markets using maximum smoothly simulated likelihood on a lagged dependent variable model, thereby allowing them to explicitly model the existence of inter temporal links between crises episodes. Methodologically, our paper is closer to the estimation technique used by Kauppi and Saikkonen (2008). These authors estimate a dynamic binary probit model to predict US recessions, using the interest rate spread as the leading variable. They observe that dynamic probit models outperform static probit models both in- and out-of-sample. Bismans and Majetti (2013) use a similar methodology to forecast recessions. Candelon et al. (2012, 2014) generalize the univariate dynamic probit model developed by Kauppi and Saikkonen (2008) to a multivariate setting and also apply it to forecast crises.

To further explore the information content of the time series available, we extend the previous literature and explore the signalling power of exuberance indicators. Our approach is simple and intuitive. Given that systemic banking crises are rare events of large magnitude, we try to explore the signalling properties embedded in the distribution of the explanatory variables used in our early warning models. To the best of our knowledge, this is the first paper using this approach. Our results show that giving more strength to specific values of the distribution of the variables may allow us to improve even further the performance of dynamic models as early warning tools. 
Finally, we deal with the difficulties associated with predicting crises that never happened, due to the successful intervention of policymakers or to favorable external developments. We are able to do so by using a database constructed by central bankers that includes both observed banking crises and also episodes of heightened vulnerability, in which the likelihood of occurrence of a crisis was perceived as very high.

This paper is organized as follows. In Section 2 we describe in detail the estimation methodology (models and parameter estimation) used and its relation to existing literature. In Section 3 we present the empirical analysis, discuss our main results, analyze the forecasting accuracy of the models and perform robustness checks. Finally, in Section 4 we summarize our main findings.

\section{Methodology}

Since the seminal work of Estrella and Hardouvelis (1991), binary response models have played an important role in the estimation and forecasting of recessions (see, for instance, Wright 2006, Kauppi and Saikkonen 2008; Nyberg 2010 ).

To introduce the models that we will use in the empirical application, consider $y_{i t}$ as the banking crisis indicator in country $i$ in period $t$, which only takes the values of one and zero (binary) and $\mathbf{x}_{i t}$ as the $(k \times 1)$ vector of exogenous variables. Let $\mathcal{F}_{t}:=\sigma\left\{\left(y_{i s}, \mathbf{x}_{i s}\right), s \leq t\right\}$ be the information set available at time $t$ and assume that, conditional on $\mathcal{F}_{t-1}, y_{i t}$ has a Bernoulli distribution with probability $p_{i t}$, i.e., $y_{i t} \mid \mathcal{F}_{t-1} \sim B\left(p_{i t}\right)$. Our objective is to model the conditional probability $p_{i t}$ as a function of the variables in $\mathcal{F}_{t-1}$. Hence, we assume, as in e.g. Kauppi and Saikkonen (2008), that the generation mechanism of $y_{i t}$ is

$$
y_{i t}=I\left(y_{i t}^{*} \geq u_{i t}\right)
$$

where $I($.$) is an indicator function, u_{i t}$ is an i.i.d. process and $y_{i t}^{*}$ is a latent variable related to the conditional probability $p_{i t}$ through the common cumulative distribution function of the random variables $u_{i t}$. Specifically, assume that $y_{i t}^{*}:=F^{-1}\left(p_{i t}\right)$ where $F($.$) is a cumulative distribution function$ which is assumed to be monotonically increasing and twice continuously 
differentiable. Thus, considering the conditional expectation and conditional probability given $\mathcal{F}_{t-1}$, it follows that

$$
E\left(y_{i t} \mid \mathcal{F}_{t-1}\right)=P\left(y_{i t}^{*} \geq u_{i t} \mid \mathcal{F}_{t-1}\right)=F\left(y_{i t}^{*}\right)=p_{i t} .
$$

In the literature, it is typically assumed that $u_{i t}$ has either a normal or a logistic distribution such that the resulting model is either a probit or a logit model, respectively. Furthermore, as suggested by Jackman (1998) one can classify models of discrete data into two general classes: i) as marginal models or ii) as transitional models.

\subsection{Marginal models}

Marginal models are only concerned with explaining the effects of covariates on the probability outcomes and treat serial dependence as a nuisance which is captured through association parameters. In these models there is no explicit conditioning on the history of the discrete response.

For the purpose of the empirical analysis below, the marginal model we consider is

$$
y_{i t}^{*}=\alpha+\sum_{k=1}^{p} \sum_{j=1}^{d} \beta_{j k} x_{i j, t-k}+u_{i t} .
$$

Note that ordinary probit models make the restrictive assumption that all observations are independent, and hence no dynamics of the dependent variable is considered. However, given that when observations over time (time series) are available, time dependence may exist and explicitly accounting for this dynamics may be of interest.

It is known in the literature that estimates from conventional probit models, i.e. estimates obtained under the assumption of independence, are consistent and asymptotically normal under serial correlation (Poirier and Ruud 1988). However, probit standard errors will be incorrect, originating wrong inference. To detect this potential problem, tests for serial correlation and robust estimation procedures of standard errors are available in the literature; see, for instance, Gourieroux et al. (1982) and Liang and Zeger (1986). However, these procedures do not explicitly model the dynamics; they are only aimed at correcting the standard errors to improve inference.

An alternative approach, which is the one we prefer and also follow in this paper, is to explicitly account for the dynamics parametrically through 
augmentation of the model with lags of either the latent variable or the binary crisis indicator.

\subsection{Transitional models}

As highlighted by Jackman (1998) "as the length of the series becomes longer, the serial component of the data is less a 'nuisance' and perhaps more a 'feature' of the data, and so in these circumstances a transitional model might be preferred to a marginal model."

Transitional models explicitly incorporate the history of the response in the computation of the latent variable $y_{i t}^{*}$. Hence, in this way, each unit specific history can be used to generate forecasts for that specific unit, as opposed to marginal models which make forecasts solely on the basis of information on the exogenous variables. Furthermore, within this class Cox et al. (1981) distinguishes two types of transitional models: a) observation driven models, where the transitions are with respect to observed data, and b) parameter driven models, where the transitions are with respect to a latent process and a threshold parameter.

2.2.1. Observation-driven transitional models. The observation-driven transitional models assume that past realizations of the discrete response are informative about the current response, and are therefore introduced in the model as additional predictors. A two-state Markov chain is a straightforward way to model a binary time series, and forms the basis of the transitional model. Since with binary data there are only two unique elements of the 2-by-2 transition matrix of a first order Markov chain, a simple way to relate covariates to the transitional probabilities is via a link function and a regression model for each of the two transition probabilities (Jackman 1998).

Hence, for the purpose of our analysis, a simple specification is the dynamic probit model,

$$
y_{i t}^{*}=\alpha+\sum_{k=1}^{p} \sum_{j=1}^{d} \beta_{j k} x_{i j, t-k}+\sum_{k=1}^{p} \gamma_{k} y_{i, t-k}+v_{i t}
$$

where $y_{i, t-k}, k=1, \ldots, p$, corresponds to the binary crisis indicator variable for country $i$ at time $t-k$. 
Beck et al. (2001) define a model such as (3) as a "restricted transition" model. Essentially, in this model the latent variable, $y_{i t}^{*}$, is simply shifted up/down by $\gamma_{k}, k=1, \ldots, p$, when $y_{i, t-k}$ is equal to one. However, as Beck et al. (2001) also indicate, the probabilities do not shift as a simple function of $\gamma_{k}, k=1, \ldots, p$, due to the nonlinear nature of the probit. The main argument for the use of this type of models is the belief that past realized values of $y_{i t}$ can be informative about its current value.

2.2.2. Exuberance Indicator. A further extension considered in our empirical application aimed at capturing periods in which explanatory variables display exuberant behaviour are considered as

$$
y_{i t}^{*}=\alpha+\sum_{k=1}^{p} \sum_{j=1}^{d} \beta_{j k} x_{i j, t-k}+\sum_{k=1}^{p} \gamma_{k} y_{i, t-k}+\sum_{k=1}^{p} \sum_{j=1}^{d} \delta_{j k} D_{i j, t-k}^{\kappa}+v_{i t}
$$

where $D_{i j, t-k}^{\kappa}$ is a dummy variable which is equal to one when variable $i$ in country $j$ exceeds its $\kappa$ percentile $(\kappa \in(0,1))$ and is zero otherwise. Note that the $\kappa$ threshold is not necessarily the same for all variables considered. In particular, in our empirical analysis, the choice consists in choosing the percentile for each of the variables considered which provides the largest AUROC.

This allows to embed into the analysis non-linearities of the independent variables. Given the rare frequency of crises and the non-linearities in the data usually observed around these events, this extension of the model may help in improving the forecasting accuracy of our estimates.

2.2.3. Parameter-driven transitional models. In contrast to the observation driven transitional models described above, in the parameter-driven transitional models the transitions are determined by the latent variable $y_{i t}^{*}$ instead of $y_{i t}$. This approach combines familiar time series methods for continuous variables with standard response models. In particular, in our analysis we consider that

$$
y_{i t}^{*}=\alpha+\sum_{k=1}^{p} \sum_{j=1}^{d} \beta_{j k} x_{i j, t-k}+\sum_{k=1}^{p} \varphi_{k} y_{i, t-k}^{*}+a_{i t} .
$$


The difference between model (3) and model (5) resides in that the former uses realized values of $\left\{y_{i t}\right\}$, whereas in the latter the underlying latent variable is used (Beck et al., 2002).

Although model (5) looks more like a conventional time series model, it is harder to estimate. The resulting likelihood function for the binary response model with autoregressive errors is considerably more complex than the likelihood in the serially independent case.

\subsection{Parameter Estimation}

In a recent paper, de Jong and Woutersen (2011) provide conditions under which a dynamic process is stationary and strong mixing. However, to the best of our knowledge for a general model such as (5) no results are available yet in the literature. Nevertheless, as argued in Kauppi and Saikkonen (2008), it seems reasonable to expect that a necessary condition for such a result is that the parameters $\varphi_{1}, \ldots, \varphi_{p}$ in (5) satisfy the usual stationarity condition, i.e., that the roots of the polynomial $\left(1-\varphi_{1} z-\ldots-\varphi_{p} z^{p}\right)$ lie outside the unit circle.

Regarding parameter estimation of the models introduced, consider the general representation

$$
y_{i t}^{*}=\mathbf{Z}_{i t}^{\prime} \theta+u_{i t}
$$

where $\mathbf{Z}_{i t}$ is a $(d \times 1)$ vector of explanatory variables which differs according to the model considered in (2), (3), (4) and (5), $\theta$ is the corresponding vector of parameters and $u_{i t}$ is an n.i.i.d. $\left(0, \sigma^{2}\right)$.

Considering that we have observed data on $y_{i t}$ and $\mathbf{Z}_{i t}$ for $t=1, \ldots, T$ and that $p$ initial values $y_{i,-p+1}, \ldots, y_{i, 0}$ are available. Then, the (conditional) loglikelihood function in a Probit type framework has the form,

$$
\ell(\theta)=\sum_{i=1}^{N} \sum_{t=1}^{T}\left[y_{i t} \log \Phi\left(y_{i t}^{*}(\theta)\right)+\left(1-y_{i t}\right) \log \left(1-\Phi\left(y_{i t}^{*}(\theta)\right)\right)\right]
$$

where $\Phi(\cdot)$ corresponds to the Normal cumulative distribution function. Note that when specification (5) is used, also the initial values $y_{i,-p+1}^{*}, \ldots, y_{i, 0}^{*}$ are needed.

The maximization of the log-likelihood function in (7) is a highly nonlinear problem, but it can be straightforwardly carried out by standard numerical methods. In the case of a specification as in (5) in a time series context, de Jong 
and Woutersen (2011) showed that, under appropriate regularity conditions, the conventional large sample theory applies to the ML estimator of the parameter vector $\theta$, denoted by $\widehat{\theta}$. The assumed regularity conditions include stationarity of the explanatory variables and normality of the random variable $u_{i t}$, and the obtained result are

$$
T^{1 / 2}(\widehat{\theta}-\theta) \stackrel{d}{\rightarrow} N\left(0, \mathcal{I}(\theta)^{-1}\right)
$$

where $\mathcal{I}(\theta)=\operatorname{plim} \sum_{i=1}^{N} \sum_{t=1}^{T}\left[\left(\frac{\partial l_{i t}(\theta)}{\partial \theta}\right)\left(\frac{\partial l_{i t}(\theta)}{\partial \theta}\right)^{\prime}\right]$ and $\stackrel{d}{\rightarrow}$ denotes convergence in distribution.

de Jong and Woutersen (2011) also note that their results on ML estimation are valid when the normality assumption does not hold. A misspecification may result when the model is used for forecasting. Specifically, if at time $t$ the purpose is to forecast the value $y_{i, t+h}(h \geq 1)$ this will require forecasts of the explanatory variables. However, if one is unwilling to build a forecasting model for the explanatory variables, one can modify the model specifications by replacing $\mathbf{Z}_{i t}$ by $\mathbf{Z}_{i, t-h}$ (see e.g. Estrella and Mishkin 1998). Thus, if the data generation process is any of the models previously discussed, such a modification results in misspecified models when $h>0$.

For inference purposes (following Chortareas et al. 2010 ) we use a NeweyWest $[\mathrm{NW}]$ type estimator of the parameters' variance/covariance matrix, adapted to a pooled panel data model, which is robust to the presence of heteroscedasticity and autocorrelation in the residuals. The Newey-West procedure has been used by Estrella and Rodrigues (1998) and Kauppi and Saikkonen (2008) when working with probit models using only time series data.

Berg and Coke (2004) also introduced a robust covariance matrix estimator for pooled static panel probit models. However, this estimator does not account for the presence of different clusters (e.g. countries). Therefore, following the suggestion of Chortareas et al. (2010), Berg and Coke s (2004) estimator for the covariance matrix of the parameters is modified as recommended by Petersen (2009). This author focused on the estimation of the standard errors of linear panel data models, by applying a NW estimator to each cluster (e.g. country) in the pooled panel.

Remark: An alternative approach for the estimation of the variance/covariance matrix is through bootstrap methods. The basic idea is simple: 
i) draw, with replacement, from the set of actual data used to estimate the model. In other words, start with an empty data set and pick a country at random and include the actual data from that country in the data set. This is repeated, with replacement, as many times as there are countries in the sample. ii) Estimate $\theta$ as described above and define the resulting estimate as $\widehat{\theta}^{B}(j)$. iii) Repeat $j$ times and then estimate the bootstrap variance of $\widehat{\theta}, \Omega_{\theta}^{B}$, as the variance of $\widehat{\theta}^{B}(j)$ across the $j$ samples; see Berg and Coke (2004) for more details.

In the next section we will estimate and evaluate the forecast performance of the models introduced in (2)-(5) in order to empirically analyze the different specifications and dynamic components considered for the development of early warning tools.

\section{Empirical Analysis}

\subsection{Data}

The most critical variable for our analysis is $y_{i t}$, the binary crisis indicator. Several authors have constructed extensive databases of financial crises (Reinhart and Rogoff 2011, Laeven and Valencia 2012). However, as noted by Chaudron and De Haan (2014), there are sizeable differences across the databases of systemic banking crises publicly available. Furthermore, Boyd et al. (2009) argue that in many cases crisis dates reflect government actions undertaken in response to bank distress and not the emergence of the distress in itself. To ensure the best quality possible for this critical variable, we use the systemic banking crises database collected by the Czech National Bank (Babeckỳ et al. 2012). This database benefited from the inputs of the Heads of Research of the Eurosystem. The database was recently updated with contributions from the European Systemic Risk Board (ESRB) Expert Group on establishing guidance for setting countercyclical buffer rates (see Detken et al. 2014, for further details). This database considers two different definitions of crises: one with actual banking crises and another which also includes episodes of heightened vulnerability which could, ex post, have justified the implementation of macroprudential tools, even if no crisis has effectively 
occurred. Our analysis focuses on the broader crisis definition, but the results are broadly robust for the stricter crisis definition as well as with other publicly available crisis databases.

To identify the variables with stronger signaling properties ahead of crisis, we used several macroeconomic and financial variables from various data sources: private credit (from the BIS and the IMF); house prices (EU, BIS and OECD data); equity prices (EU and IMF); nominal and real GDP (EU, IMF); and debt service ratio (BIS, ECB and EUROSTAT; calculations were performed by the ECB based on the methodology by Drehmann and Juselius, 2012). In addition, also several bank variables were considered: net interest income (OECD), net pre-tax income (OECD), capital and reserves (OECD, $\mathrm{EU})$, leverage ratio (EU), and total assets (EU) ${ }^{2}$

The longest series in the dataset span from 1970Q1 to 2010Q4. The results presented in our paper rely on an updated version of the dataset initially provided by the ECB, using Thomson Reuters. To maximize the information set available, in some cases we extended the series from a given source with data from other sources available in the dataset. When the data sources were not the same, the series were extended using chain growth rates with data up to 2013Q2 3 In some cases, the series were also extended back to previous periods. Most variables are provided on a quarterly basis.

In order to ensure that the data used in the estimations replicates as closely as possible the data available to policy makers in each moment of time, we used lagged variables to consider lags in data releases and we computed only onesided or recursive filters. Despite these efforts, the information is not exactly the same as that that would be available to policy makers, as many macroeconomic variables are subject to ex-post revisions. Edge and Meisenzahl (2011) show that these differences can be sizeable when computing the credit-to-GDP ratio, thereby leading to potential differences when setting macro-prudential instruments such as the countercyclical capital buffer ratio. Nevertheless, this is the best approximation possible for researchers.

We implemented a few transformations of the original variables. First, we computed several ratios, such as the credit-to-GDP and the total assets of

2. See Alessi et al. (2014) for more details.

3. The only series that was not possible to update was the debt service ratio. 
the banking system as a percentage of GDP. Second, we computed year-onyear growth rates for most of the variables. Finally, we estimated deviations from long-term trends, using one-sided Hodrick-Prescott filters with different smoothing parameters ${ }^{4}$

After performing these transformations, we obtain 35 possible explanatory variables. In order to select the potentially more relevant ones, we performed an univariate analysis, examining the AUROC of each series. In addition, the availability of information was also considered as important and the shorter series were not included in this analysis. Hence, from this analysis, we determined that the best performing variables are the credit-to-GDP gap with a smoothing parameter of $400000^{5}$ the debt service ratio, the year-on-year growth rate of house prices, and the equity price index ${ }^{6}$

Table 1 presents some descriptive statistics on these variables for the whole sample, while Table 2 displays country specific summary statistics. For some countries, there is no information for some of the variables used, thereby implying that these countries are not included in the multivariate analysis (namely, Belgium, Cyprus, Luxembourg, Malta, Poland, and Romania). The final sample thus consists of 22 European countries.

4. For an illustration of the impacts of using different smoothing parameters in a similar setting, please see Bonfim and Monteiro (2013).

5. According to the Basel Committee on Banking Supervision (2010) and Drehmann et al. (2010), the deviation of the ratio between credit and GDP from its long term trend is the indicator that better performs in signaling the need to build up capital before a crisis, when examining several indicators for different countries. Given this evidence, the Basel Committee on Banking Supervision (2010) proposes that countercyclical capital buffer decisions be anchored on the magnitude of these deviations (though recognizing the need to complement the decisions with other indicators, as well as with judgment).

6. These results are consistent with those of Drehmann and Juselius (2014), who show that the best performing indicators to forecast banking crises are the credit-to-GDP gap and the debt service ratio. They find that the former performs better at longer forecasting horizons, while the latter performs better closer to the emergence of a crisis. 
Total sample

\begin{tabular}{lcccccc} 
& $\mathbf{N}$ & Mean & St. dev. & min & Median & max \\
\cline { 2 - 6 } & 4816 & 0.10 & 0.29 & 0 & 0 & 1 \\
Crisis dummy & 2516 & 57.0 & 43.9 & 1 & 46.2 & 265.1 \\
Equity price index & 2380 & 0.19 & 0.17 & 0.01 & 0.15 & 1.08 \\
Debt service ratio & 2522 & 4.8 & 11.6 & -47.2 & 2.4 & 62.5 \\
Credit-to-GDP gap & 2252 & 9.4 & 46.2 & -42.2 & 5.4 & 1442.4 \\
House price index (yoy) & & &
\end{tabular}

TABle 1. Summary statistics

Note: yoy - year on year growth rate (\%). The crisis dummy takes the value 1 during banking crises or during periods of heightned vulnerability in which a crisis could be eminent. The equity price index combines data from Eurostat and the IMF, to obtain the longest series possible. The debt service ratio series were provided by the ECB, following the methodology of Drehmann and Juselius (2012). The credit-to-GDP ratio was computed as the ratio between domestic private credit series provided by the BIS (and in some cases extrapolated with IMF data) and nominal GDP. In turn, the credit-to-GDP gap was computed as the deviation from the long-term trend of the credit-to-GDP ratio using a one-sided HodrickPrescott filter, with a smoothing parameter of 400.000 . The house price index combines data from the BIS and OECD.

Sources: Babeckỳ et al. (2012), BIS, ECB, Detken et al. (2014), Eurostat, IMF, OECD, Thomson Reuters, and authors' calculations. 
Equity price index Debt service ratio Credit-to-GDP gap House price index (yoy) Crisis dummy

\begin{tabular}{|c|c|c|c|c|c|c|c|c|c|c|}
\hline & $\mathbf{N}$ & median & $\mathbf{N}$ & median & $\mathbf{N}$ & median & $\mathbf{N}$ & median & $\mathbf{N}$ & mean \\
\hline Austria & 172 & 32.7 & 171 & 0.15 & 167 & 0.5 & 127 & 2.83 & 172 & 0.00 \\
\hline Belgium & & & & & & & & & 172 & 0.00 \\
\hline Bulgaria & 54 & 48.0 & 64 & 0.06 & 57 & 13.4 & 127 & 3.00 & 172 & 0.13 \\
\hline Cyprus & & & & & & & & & 172 & 0.02 \\
\hline Germany & 172 & 53.8 & 170 & 0.15 & 167 & -1.4 & 127 & 2.82 & 172 & 0.09 \\
\hline Dennmark & 93 & 65.7 & 39 & 0.25 & 139 & 2.9 & 127 & 5.11 & 172 & 0.27 \\
\hline Estonia & 66 & 54.6 & 65 & 0.13 & 67 & 1.9 & 28 & 7.02 & 172 & 0.02 \\
\hline France & 100 & 77.7 & 171 & 0.13 & 167 & 1.9 & 127 & 3.61 & 172 & 0.16 \\
\hline Greece & 80 & 67.9 & 45 & 0.14 & 127 & 1.9 & 127 & 11.50 & 172 & 0.12 \\
\hline Croatia & 61 & 89.1 & 7 & 0.17 & 45 & 3.4 & 60 & 3.50 & 172 & 0.06 \\
\hline Hungary & 88 & 42.4 & 71 & 0.08 & 83 & 4.3 & 83 & 9.13 & 172 & 0.10 \\
\hline Ireland & 172 & 30.1 & 131 & 0.21 & 127 & 9.2 & 127 & 6.66 & 172 & 0.10 \\
\hline Italy & 172 & 38.5 & 171 & 0.13 & 167 & 6.1 & 127 & 5.44 & 172 & 0.05 \\
\hline Lithuania & 48 & 77.4 & 72 & 0.05 & 61 & 3.5 & 53 & 9.75 & 172 & 0.10 \\
\hline Poland & & & & & & & & & 172 & 0.00 \\
\hline Portugal & 100 & 81.9 & 143 & 0.25 & 139 & 13.7 & 125 & 4.20 & 172 & 0.13 \\
\hline Romania & & & & & & & & & 172 & 0.05 \\
\hline Sweden & 172 & 24.0 & 171 & 0.75 & 127 & 1.0 & 127 & 6.13 & 172 & 0.14 \\
\hline Slovenia & 62 & 55.2 & 36 & 0.13 & 43 & 1.2 & 20 & -0.16 & 172 & 0.19 \\
\hline Slovakia & 70 & 44.4 & 28 & 0.10 & 59 & 0.3 & 75 & 6.82 & 172 & 0.00 \\
\hline United Kingdom & 172 & 46.1 & 171 & 0.21 & 167 & 3.5 & 168 & 8.84 & 172 & 0.27 \\
\hline Total & 2516 & 46.2 & 2380 & 0.15 & 2522 & 2.4 & 2252 & 5.37 & 4816 & 0.10 \\
\hline
\end{tabular}

TABLE 2. Summary statistics by country

Note: all variables are defined in Table 1 .

Sources: Babeckỳ et al. (2012), BIS, ECB, Detken et al. (2014), Eurostat, IMF, OECD, Thomson Reuters, and authors' calculations. 
Equity prices reached higher median values in Croatia, Portugal, France and Lithuania and were more subdued in Finland, Sweden and Spain. The highest debt service ratio was observed in Sweden, while in Latvia, Lithuania, Hungary and Bulgaria this ratio stood closer to zero. The credit-to-GDP gap, which has been found to be one of the best predictors of banking crises (Drehmann et al. 2010), displays a negative median value for Germany and relatively low median values in Slovakia and Austria. The highest median values for this gap are observed in Bulgaria, Portugal, Ireland, Italy and Latvia. Finally, house prices have increased more significantly in Greece, the UK, Hungary and Lithuania, and displayed a smaller magnitude in Germany, Austria, Slovenia and Latvia.

\subsection{Main results}

The first step in the analysis consisted of the estimation of the models described in Section 2 and variants of these. For reference purposes, we will refer to the models in (2) as simple probit models, to the models in (3) as dynamic probit models, to the models in (4) as exuberance probit models and finally to the models in (5) as latent probit models. Thus, considering $y_{i t}$, the endogenous binary response indicator of banking crisis, the multistep ahead projections were obtained through pooled panel probit specifications, where the conditional probability forecast of observing a crisis at time $t, P\left(y_{i t}=1\right)$, is given by $\Phi\left(y_{i t}^{*}\right)$. In particular, $\Phi(\cdot)$ is the Gaussian cumulative distribution function and $y_{i t}^{*}$ is a latent variable. Defining $h$ as the forecast horizon, we adjust (6) to produce the necessary forecasts from,

$$
y_{i t}^{*}=\mathbf{Z}_{i, t-h}^{\prime} \theta+v_{i t} .
$$

The model was estimated with three different lag structures. First we considered 4 to 20 lags of all explanatory variables $\left(\mathbf{Z}_{i, t-4}, \ldots, \mathbf{Z}_{i, t-20}\right)$, which allowed us to analyse the determinants of banking crisis 1 to 5 years in advance. In addition, we estimated the model in a so-called "early period", exploring the crisis determinants with a lag between 12 and 20 quarters. This allowed us to identify the variables with stronger early warning signals, thus giving enough time for policymakers to act. Finally, we also estimated the model in the "late period", using information lagged between 4 and 12 quarters, to understand which variables may be more relevant to signal a crisis in the near future. In 
this period, signals may be stronger and policy action may need to be prompter.

A similar reasoning is presented by Oet et al. (2013). 


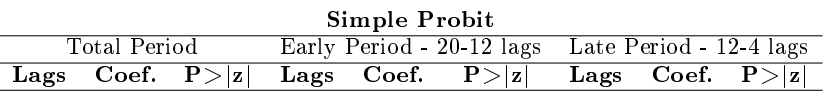

\begin{tabular}{ccc}
\multicolumn{3}{c}{ Dynamic probit } \\
\hline Total Period & Early Period - 20-12 lags & Late Period - 12-4 lags
\end{tabular}

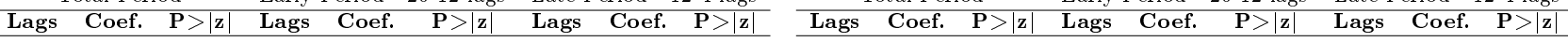

Crisis dummy

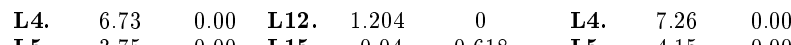

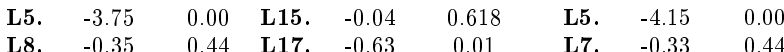

Equity price index

L17. $-1.05 \quad 0.00$

\begin{tabular}{|c|c|c|c|c|c|c|c|c|c|}
\hline \multirow[t]{5}{*}{ Equity price index } & L12. & 0.00 & 0.24 & L12. & 0.01 & 0.01 & L6. & 0.00 & 0.84 \\
\hline & L15. & 0.00 & 0.80 & L15. & 0.00 & 0.02 & L12. & & \\
\hline & L17. & 0.00 & 0.68 & L17. & 0.00 & 0.77 & & & \\
\hline & & & & L18. & 0.01 & 0.00 & & & \\
\hline & & & & L19. & -0.01 & 0.02 & & & \\
\hline \multirow[t]{7}{*}{ Debt service ratio } & L7. & 8.08 & 0.01 & L12. & 11.01 & 0.003 & L4. & 0.45 & 0.17 \\
\hline & L12. & 3.05 & 0.17 & L15. & -4.24 & 0.397 & & & \\
\hline & L14. & -3.89 & 0.14 & L20. & -6.93 & 0.031 & & & \\
\hline & L15. & 0.93 & 0.63 & & & & & & \\
\hline & L16. & 2.55 & 0.48 & & & & & & \\
\hline & L17. & -5.37 & 0.08 & & & & & & \\
\hline & L20. & -5.94 & 0.17 & & & & & & \\
\hline \multirow[t]{4}{*}{ Credit-to-GDP gap } & L6. & -0.05 & 0.01 & L14. & 0.024 & 0.059 & L4. & -0.05 & 0.03 \\
\hline & L9. & 0.04 & 0.00 & & & & L5. & 0.01 & 0.44 \\
\hline & L14. & 0.02 & 0.15 & & & & L6. & 0.01 & 0.27 \\
\hline & & & & & & & L9. & 005 & 0.00 \\
\hline
\end{tabular}

L9. $\quad \begin{array}{lllll}-0.01 & 0.06 & \text { L12. } & 0.013 & 0.005\end{array}$

$\begin{array}{llllll}\text { L11. } & 0.00 & 0.82 & \text { L13. } & -0 & 0.176 \\ \text { L18. } & 0.00 & 0.94 & \text { L17. } & 1 \text { - } 04 & 0.952\end{array}$

L6. $\quad 0.01 \quad 0.05$

$\begin{array}{llll}0.94 & \text { L19. } & -0.01 & 0.153 \\ & & & \end{array}$

$\begin{array}{llllccccc}\text { L4. } & 27.26 & 0.00 & \text { L12. } & 14.2 & 0 & \text { L4. } & 17.52 & 0.00 \\ \text { L6. } & -7.16 & 0.06 & \text { L14. } & -7.94 & 0.027 & \text { L7. } & -17.56 & 0.00\end{array}$

$\begin{array}{lllllr}\text { L6. } & -7.16 & 0.06 & \text { L14. } & -7.94 & 0.027 \\ \text { L7. } & -5.71 & 0.20 & \text { L20. } & -6.59 & 0.02\end{array}$

L10. $-8.03 \quad 0.06$

$\begin{array}{lll}\text { L14. } & -0.39 & 0.95 \\ \text { L18. } & -7.68 & 0.10\end{array}$

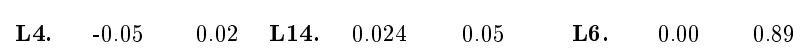

L6. 0.010 .61

$\begin{array}{rrr}\text { L9. } & 0.03 & 0.12 \\ \text { L10. } & 0.01 & 0.65 \\ \end{array}$

$\begin{array}{rrr}\text { L11. } & 0.05 & 0.04 \\ \text { L13. } & -0.03 & 0.07\end{array}$

L13. $\quad-0.03 \quad 0.07$

House price index (yoy)

Constant

$\begin{array}{rrrrrr} & & & \text { L16. } & 0.00 & 0.92 \\ \text { L5. } & -0.05 & 0.04 & \text { L12. } & -0.01 & 0.61 \\ \text { L6. } & 0.03 & 0.03 & \text { L20. } & 0.00 & 0.62\end{array}$

$-1.95 \quad 0.00$
-0.07

0.57

0.57
1395

$-1.55$

$\begin{array}{rrr}\text { L12. } & -0.07 & 0.00\end{array}$

$R^{2}$
$\mathrm{~N}$

$\begin{array}{rr}0.18 & 0.15 \\ 1721 & 1749\end{array}$

0.18
1585

0.20
1749

$\begin{array}{lrr}\text { L5. } & -0.01 & 0.32 \\ \text { L9. } & 0.01 & 0.21\end{array}$

0.5417
49

TABLE 3. Regression results: simple and dynamic probits

Note: all variables are defined in Table 1 . The total period refers to lags [20;4], the early period [20;12] and the late period [12;4]. Standard errors clustered by country.

Sources: Babecky et al (2012), BIS, ECB, Detken et al. (2014), Eurostat, IMF, OECD, Thomson Reuters, and authors' calculations. 
For all models, we began by estimating the regressions with all the lags of the four selected explanatory variables (equity price index, debt service ratio, credit-to-GDP gap, and the year-on-year-growth rate of the house price index). From that estimation, we selected only the variables which were statistically significant at a $10 \%$ nominal level, thereby allowing us to re-estimate a more parsimonious model. The results of this second round of estimates are presented in Table 3. The first three columns show the results for the marginal model defined in (2) (simple probit) and the last three show the results for the transition model defined in (3).

In the full period estimation, the equity price index is never statistically significant in this specification. In contrast, the public debt service ratio is statistically significant (at a 10\% nominal level) at several quarters $(t-k$, for $k=7$ and 17). The credit-to-GDP gap displays several statistically significant coefficients $(t-6$ and $t-9)$. However, the signs of these coefficients are not always consistent, i.e., in some quarters the estimated coefficients are positive, whereas in others they turn out to be negative. Finally, the year-on-year growth rate of house prices is absent from this specification, as this variable was never significant in the first step of the estimation.

In the early period $(t-12$ to $t-20)$, the results are somewhat different. The debt service ratio appears significant at $t-12$ and $t-20$, albeit with different coefficient signs. Equity price indices display significant coefficients with a lag of 12, 15, 18 and 19 quarters, suggesting that this variable may provide useful indications well ahead of crisis. The credit-to-GDP gap is only relevant at $t-14$.

In the period closer to the crisis, the so called late period $(t-4$ to $t-12)$, the results are also different. Both the debt to service ratio and the equity price index are not statistically significant at any lag, while the credit-to-GDP gap is significant at $t-4$ and $t-9$. House price index growth turns out to be significant at $t-5$ and $t-6$, showing that the variables have different signaling powers in different horizons.

In the second part of Table 3 we present the results for the dynamic models (model (3)). As discussed before, by exploring the dynamics embedded in a crises time series, we hope to be able to improve the quality of our early warning model. Indeed, including lagged dependent variables in the model specification seems to substantially improve the model fit. Several lags of the dependent 
variable turn out to be statistically significant in explaining the likelihood of occurrence of a systemic banking crisis, in the three different estimation windows considered. The results concerning the other explanatory variables are broadly consistent. The main difference is perhaps that the debt service ratio is now more significant in several specifications.

In the Appendix, we provide the estimation results for the models (4) and (5).

All in all, the equity price index and the debt to service ratio seem to provide useful early guidance for policymakers while the credit-to-GDP gap has better signaling properties closer to the emergence of a crisis.

\subsection{Model assessment}

The main goal of this exercise is to provide useful early-warning guidance to policymakers ahead of systemic banking crises. To test how useful the guidance provided by the models may be, several assessment metrics may be considered.

Since the model is a binary response one, we can define a cut-off value for the latent variable. The observation is classified by the model as "crisis" if the latent variable is above the cut-off; and as "non-crisis" otherwise. This procedure defines, for each cut-off, a classification for each observation in the sample. Notice that we know from the data the actual classification of each observation, that is, what actually happened in each country-quarter pair of the sample. Naturally, a perfect model would classify correctly all observations. This does not happen in practice. As a matter of fact, a very low value for the cut-off means that a lot of non-crisis observations are going to be classified by the model as crisis (this is the so-called type I error, and we can think of it as a false alarm). As we increase the cut-off, more and more non-crisis observations are going to be classified as such by the model but some observations that actually are crisis are going to be classified as non-crisis (this is the type II error, or a "wolf in a sheep's clothing"). When the cut-off is very high, all observations are classified as non-crisis - and so all crisis observations will be wrongly classified as non-crisis by the model.

[Please insert Figure 1 about here]

We define specificity as the fraction of non-crisis observations that are classified as non-crisis by the model, and as sensitivity the fraction of crisis 
observations that are classified as crisis by the model. When the cut-off is minus infinity, all observations are classified as crisis by the model; therefore, sensitivity is 1 and specificity is 0 . When the cut-off is plus infinity, sensitivity is 0 and specificity is 1 . By varying the cut-off we obtain a set of values for these two measures. A possible representation of the model's performance is the Receiver Operating Characteristic (ROC) curve (Figure 1). In the horizontal axis we represent 1 minus specificity, that is, the percentage of non-crisis observations classified as crisis by the model. In the vertical axis we represent sensitivity, that is, the fraction of crisis observations classified as crisis by the model. A given point $(x, y)$ on the curve answers the following question: What percentage $x$ of non-crisis observations will be incorrectly classified by the model in order to classify correctly a percentage $y$ of crisis observations?

As previously indicated, in a perfect model we would have to incorrectly classify 0 percent of the non-crisis observations in order to correctly classify 100 percent of crisis observations. This means that the perfect model's ROC curve would be the line segment between points $(0,1)$ and $(1,1)$. On the other hand, a model randomly classifying observations will have a ROC curve given by the line segment between points $(0,0)$ and $(1,1)$, i.e., a $45^{\circ}$ degree line. In other words, the model would incorrectly classify 25 percent of the noncrisis observations to correctly classify 25 percent of the crisis observations, and so forth. This fact suggests that an adequate measure for the performance of the model is the area under the ROC curve, commonly known as AUROC. Figure 1 illustrates two hypothetical ROC curves, with different sensitivity and specificity values. 


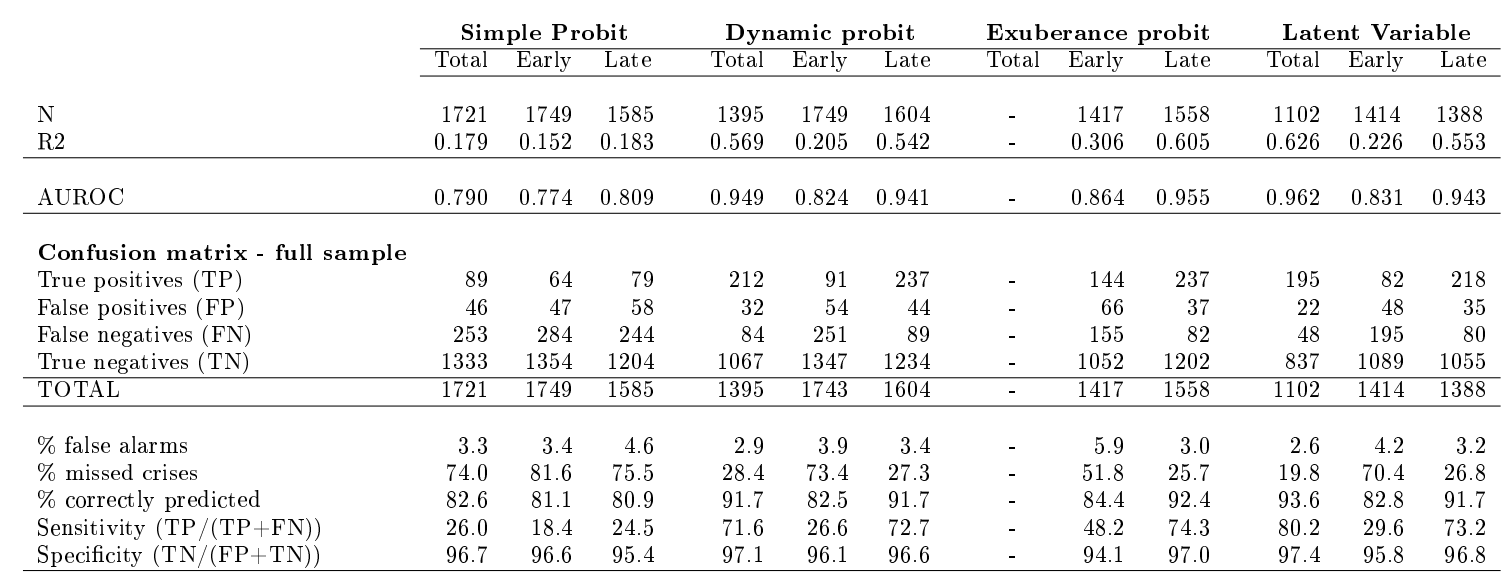

TABLE 4. Model Evaluation

Note: the results refer to the regressions presented in Table 3 and in the Appendix. The total period refers to lags [20;4], the early period [20;12] and the late period $[12 ; 4]$. The model with exuberance indicators does not converge when the entire period is considered.

Sources: Babeckỳ et al. (2012), BIS, ECB, Detken et al. (2014), Eurostat, IMF, OECD, Thomson Reuters, and authors' calculations. 
Figure 2 plots the ROC curves for the specifications presented in Table 3 (simple and dynamic probits), while Figure 3 plots similar curves for probits with exuberance indicators and latent variables. Table 4 presents several indicators to assess the quality of these models: the number of true positives (TP - number of correctly predicted crisis periods), the number of true negatives (TN), the number of false positives (FP) and the number of false negatives (FN). These elements can be used to compute two performance measures for binary classification tests: the sensitivity, defined as the true positives rate $(\mathrm{TP} /(\mathrm{TP}+\mathrm{FN}))$, and the specificity, defined as 1 minus the false positive rate. We also present results for the percentage of false alarms, the percentage of missed crises and the percentage of correctly predicted crises.

[Please insert Figures 2 and 3 about here]

Examining the model's goodness of fit (McFadden's $\mathrm{R}^{2}$ ) and the AUROC provides indication on the quality of the model. The early period estimations provide the weakest results. This is not surprising, as it would be expected that signals are stronger immediately before the crisis than 3 years before.

Regarding the methodology, the model's performance, assessed by McFadden's $\mathrm{R}^{2}$ and the AUROC, is substantially better when we include dynamic components, i.e., the lagged dependent (both the observed or latent) variable. This shows that exploring the dynamics of the dependent variable helps to significantly improve the performance of the model, in all the estimation horizons considered. Further, the addition of exuberance indicators improves the model even more, although only for early and late period configurations (for the total period, convergence was not achieved for this model).

Although the model's goodness of fit and the AUROC are useful summary measures to assess the performance of each model, it is also relevant to consider how many crises the models correctly predict, how many they fail to predict and how many false alarms exist. This is relevant especially in a setting such as ours, with potentially relevant implications for decision-making. Indeed, as noted by Alessi and Detken (2011), Betz et al. (2014), Bussière and Fratzscher (2006) or Davis and Woutersen (2008), policymakers are not indifferent between missing a crisis or acting upon false alarms. As there is a trade-off between these two 
dimensions, which are subsumed in the AUROC, it might be relevant to look at them separately.

Dynamic probit models are able to reduce the percentage of false alarms for the total and late periods estimation. Nevertheless, this percentage is very small in all models (at most 5.9 per cent). In contrast, dynamic probit models significantly reduce the percentage of missed crises (from 74 to 28.4 per cent, in the total period estimation). Given that missing a crisis may be costlier than issuing a false alarm (Borio and Lowe 2002, Demirgüç-Kunt and Detragiache 2005 Borio and Drehmann 2009), this result suggests that dynamic models may be very useful for policymakers. In addition, dynamic models are able to correctly predict a larger percentage of crisis episodes, most notably in the total and late periods considered.

It is also interesting to see that dynamic probit models show significantly increased sensitivity. As mentioned above, sensitivity is defined as the number of true positives as a percentage of the total number of crises, thereby being a so-called true positive rate. This confirms that dynamic probits are more helpful in identifying crisis periods than marginal models. In turn, the specificity of the model, which is defined as the true negatives as a percentage of the total non-crises periods, also increases slightly in the dynamic models, except in the early period.

All in all, a large battery of metrics confirms that adding a dynamic component to early warning crises models substantially improves the quality of the results, most notably in reducing the percentage of missed crises and in increasing the percentage of those that are correctly predicted.

Adding exuberance terms to the estimation improves these results even further. The evaluation metrics improve in all the estimation horizons. The only exception is the percentage of false alarms in the early period. The dynamic model with exuberance indicators misses $51.8 \%$ of the crises in the sample of the early period setup, while in the late period configuration it misses only $25 \%$. The performance of the model is substantially better when we consider the percentage of correctly predicted crises.

Regarding the estimation with lags of the latent variable, the results provide a slight improvement over the dynamic model introduced before. In turn, this model slightly underperforms the one including exuberance indicators. 
In sum, our results show that accounting for the dynamics in the dependent variable and the exuberance indicators for the independent variables allows to substantially improve the performance of early warning models for banking crises.

\subsection{Robustness}

The results presented so far assess the in-sample performance of the model. However, the quality of the model hinges on its forecasting accuracy. It is thus essential to test the model's out-of-sample performance. To do that, two different exercises were considered. First, an out-of-period estimation was implemented excluding the global financial crisis period from the sample for all countries (we excluded all quarters from 2007Q1 onwards). The second exercise was an out-of-sample estimation exercise in which Denmark, Finland and Sweden were excluded given the systemic banking crisis in the late 1980s/early 1990s. Afterwards we test the accuracy of the model for these countries ex post.

The results of the performance of the simple, dynamic and exuberance models in these two exercises are presented in Table 5 and Figures 4 to 7. The table shows several evaluation metrics for the three estimation windows considered (total, early and late periods). The in-sample results are compared to the out-of-period and out-of-sample estimations. In these two cases, the models are estimated excluding, respectively, the period and countries mentioned above. The metrics refer to the performance of the prediction of the model for these excluded observations.

\section{[Please insert Figures 4 to 7 about here]}

We find that the performance for the out-of-period estimations generally decreases in the simple probits. This is indeed a reason for concern, as a significant part of crises observations in different countries are recorded after 2007. The percentage of missed crises increases significantly in the out-ofperiod estimation, showing that the model would not be able to predict the global financial crisis in all the countries considered. The percentage of correct predictions of crises also decreases more in this estimation. These latter results are not unexpected, as this crisis was driven in many countries mainly by exogenous shocks rather than by underlying vulnerabilities. 


\begin{tabular}{|c|c|c|c|c|c|c|c|c|c|}
\hline \multirow{3}{*}{ AUROC } & \multicolumn{3}{|c|}{ Simple Probit } & \multicolumn{3}{|c|}{ Out-of-period } & \multicolumn{3}{|c|}{ Out-of-sample } \\
\hline & Total & Early & Late & Total & Early & Late & Total & Early & Late \\
\hline & 0.790 & 0.774 & 0.809 & 0.588 & 0.582 & 0.601 & 0.877 & 0.860 & 0.846 \\
\hline \multicolumn{10}{|c|}{ Confusion matrix - full sample } \\
\hline True positives & 89 & 64 & 79 & 13 & 8 & 27 & 36 & 20 & 27 \\
\hline False positives & 46 & 47 & 58 & 11 & 12 & 14 & 14 & 15 & 20 \\
\hline False negatives & 253 & 284 & 244 & 180 & 191 & 157 & 24 & 40 & 33 \\
\hline True negatives & 1333 & 1354 & 1204 & 222 & 253 & 217 & 211 & 210 & 190 \\
\hline TOTAL & 1721 & 1749 & 1585 & 426 & 464 & 415 & 285 & 285 & 270 \\
\hline$\%$ false alarms & 3.3 & 3.4 & 4.6 & 4.7 & 4.5 & 6.1 & 6.2 & 6.7 & 9.5 \\
\hline$\%$ missed crises & 74.0 & 81.6 & 75.5 & 93.3 & 96.0 & 85.3 & 40.0 & 66.7 & 55.0 \\
\hline$\%$ correctly predicted & 82.6 & 81.1 & 80.9 & 55.2 & 56.3 & 58.8 & 86.7 & 80.7 & 80.4 \\
\hline Sensitivity $(\mathrm{TP} /(\mathrm{TP}+\mathrm{FN}))$ & 26.0 & 18.4 & 24.5 & 6.7 & 4.0 & 14.7 & 60.0 & 33.3 & 45.0 \\
\hline \multirow[t]{3}{*}{ Specificity $(\mathrm{TN} /(\mathrm{FP}+\mathrm{TN}))$} & 96.7 & 96.6 & 95.4 & 95.3 & 95.5 & 93.9 & 93.8 & 93.3 & 90.5 \\
\hline & \multicolumn{3}{|c|}{ Dynamic probit } & \multicolumn{3}{|c|}{ Out-of-period } & \multicolumn{3}{|c|}{ Out-of-sample } \\
\hline & Total & Early & Late & Total & Early & Late & Total & Early & Late \\
\hline AUROC & 0.949 & 0.824 & 0.941 & 0.898 & 0.664 & 0.906 & 0.959 & 0.864 & 0.956 \\
\hline
\end{tabular}

\begin{tabular}{|c|c|c|c|c|c|c|c|c|c|}
\hline \multicolumn{10}{|c|}{ Confusion matrix - full sample } \\
\hline True positives & 212 & 91 & 237 & 110 & 22 & 128 & 47 & 25 & 45 \\
\hline False positives & 32 & 54 & 44 & 9 & 29 & 5 & 6 & 14 & 5 \\
\hline False negatives & 84 & 251 & 89 & 70 & 177 & 60 & 13 & 35 & 15 \\
\hline True negatives & 1067 & 1347 & 1234 & 198 & 236 & 231 & 170 & 211 & 201 \\
\hline TOTAL & 1395 & 1743 & 1604 & 387 & 464 & 424 & 236 & 285 & 266 \\
\hline$\%$ false alarms & 2.9 & 3.9 & 3.4 & 4.3 & 10.9 & 2.1 & 3.4 & 6.2 & 2.4 \\
\hline$\%$ missed crises & 28.4 & 73.4 & 27.3 & 38.9 & 88.9 & 31.9 & 21.7 & 58.3 & 25.0 \\
\hline$\%$ correctly predicted & 91.7 & 82.5 & 91.7 & 79.6 & 55.6 & 84.7 & 91.9 & 82.8 & 92.5 \\
\hline Sensitivity $(\mathrm{TP} /(\mathrm{TP}+\mathrm{FN}))$ & 71.6 & 26.6 & 72.7 & 61.1 & 11.1 & 68.1 & 78.3 & 41.7 & 75.0 \\
\hline \multirow[t]{3}{*}{ Specificity $(\mathrm{TN} /(\mathrm{FP}+\mathrm{TN}))$} & 97.1 & 96.1 & 96.6 & 95.7 & 89.1 & 97.9 & 96.6 & 93.8 & 97.6 \\
\hline & \multicolumn{3}{|c|}{ Exuberance probit } & \multicolumn{3}{|c|}{ Out-of-period } & \multicolumn{3}{|c|}{ Out-of-sample } \\
\hline & Total & Early & Late & Total & Early & Late & Total & Early & Late \\
\hline AUROC & - & 0.864 & 0.955 & - & 0.552 & 0.725 & - & 0.834 & 0.960 \\
\hline
\end{tabular}

\begin{tabular}{|c|c|c|c|c|c|c|c|c|c|}
\hline \multicolumn{10}{|c|}{ Confusion matrix - full sample } \\
\hline True positives & - & 144 & 237 & - & 39 & 37 & - & 26 & 46 \\
\hline False positives & - & 66 & 37 & - & 27 & 19 & - & 12 & 3 \\
\hline False negatives & - & 155 & 82 & - & 146 & 146 & - & 34 & 14 \\
\hline True negatives & - & 1052 & 1202 & - & 206 & 206 & - & 164 & 199 \\
\hline TOTAL & - & 1417 & 1558 & - & 418 & 408 & - & 236 & 262 \\
\hline$\%$ false alarms & - & 5.9 & 3.0 & - & 11.6 & 8.4 & - & 6.8 & 1.5 \\
\hline$\%$ missed crises & - & 51.8 & 25.7 & - & 78.9 & 79.8 & - & 56.7 & 23.3 \\
\hline$\%$ correctly predicted & - & 84.4 & 92.4 & - & 58.6 & 59.6 & - & 80.5 & 93.5 \\
\hline Sensitivity $(\mathrm{TP} /(\mathrm{TP}+\mathrm{FN}))$ & - & 48.2 & 74.3 & - & 21.1 & 20.2 & - & 43.3 & 76.7 \\
\hline \multirow[t]{3}{*}{ Specificity $(\mathrm{TN} /(\mathrm{FP}+\mathrm{TN}))$} & - & 94.1 & 97.0 & - & 88.4 & 91.6 & - & 93.2 & 98.5 \\
\hline & \multicolumn{3}{|c|}{ Latent Variable } & \multicolumn{3}{|c|}{ Out-of-period } & \multicolumn{3}{|c|}{ Out-of-sample } \\
\hline & Total & Early & Late & Total & Early & Late & Total & Early & Late \\
\hline AUROC & 0.962 & 0.831 & 0.943 & 0.830 & 0.626 & 0.911 & 0.812 & 0.721 & 0.871 \\
\hline \multicolumn{10}{|c|}{ Confusion matrix - full sample } \\
\hline True positives & 195 & 82 & 218 & 78 & 30 & 112 & 42 & 33 & 52 \\
\hline False positives & 22 & 48 & 35 & 10 & 35 & 8 & 20 & 71 & 38 \\
\hline False negatives & 48 & 195 & 80 & 80 & 136 & 70 & 5 & 12 & 8 \\
\hline True negatives & 837 & 1089 & 1055 & 175 & 207 & 203 & 60 & 118 & 135 \\
\hline TOTAL & 1102 & 1414 & 1388 & 343 & 408 & 393 & 127 & 234 & 233 \\
\hline$\%$ false alarms & 2.6 & 4.2216 & 3.211 & 5.4 & 14.5 & 3.8 & 25.0 & 37.6 & 22.0 \\
\hline$\%$ missed crises & 19.8 & 70.397 & 26.846 & 50.6 & 81.9 & 38.5 & 10.6 & 26.7 & 13.3 \\
\hline$\%$ correctly predicted & 93.6 & 82.815 & 91.715 & 73.8 & 58.1 & 80.2 & 80.3 & 64.5 & 80.3 \\
\hline Sensitivity $(\mathrm{TP} /(\mathrm{TP}+\mathrm{FN}))$ & 80.2 & 29.603 & 73.154 & 49.4 & 18.1 & 61.5 & 89.4 & 73.3 & 86.7 \\
\hline Specificity $(\mathrm{TN} /(\mathrm{FP}+\mathrm{TN}))$ & 97.4 & 95.778 & 96.789 & 94.6 & 85.5 & 96.2 & 75.0 & 62.4 & 78.0 \\
\hline
\end{tabular}

TABLE 5. Out-of-sample and out-of-period estimation

Note: the results for the out-of-sample exercise exclude Denmark, Finland and Sweden, where there was a systemic banking crisis in the late 1980s/early 1990s, and the results for the out-of-period exclude the global financial crisis that started in 2007 . The total period refers to lags $[20 ; 4]$, the early period $[20 ; 12]$ and the late period $[12 ; 4]$.The model with exuberance indicators does not converge when the entire period is considered.

Source: Babeckỳ et al. (2012), BIS, ECB, Detken et al. (2014), Eurostat, IMF, OECD, Thomson Reuters, and authors' calculations. 
However, when we consider dynamic models, the decrease in performance is milder. This is a relevant result, showing that even though it would be quite challenging to predict the global financial crises, adding a dynamic component to the model would help policymakers to be more successful in detecting heightened vulnerabilities at an early stage.

In turn, the performance of the models in the out-of-sample exercises is actually better than that of the baseline estimations in some cases. This means that the models are able to perform well when we exclude the Nordic crisis from the sample. However, this improved performance might be driven by the fact that most crisis events left in the database now refer to the global financial crisis.

Looking at the different models, the results show that the dynamic component is the main source of improvement from the simple probit regression. Despite being slightly outclassed by the exuberance and latent variable approach (through the in-sample AUROC), its results' consistency over all periods and its performance in the out-of-sample and out-of-time exercises show that this may be the most reliable model.

\section{Concluding Remarks}

Systemic banking crises are rare, yet extremely costly, events. Despite the large body of existing literature, accurately predicting crises is still a very challenging exercise. In this paper, we provide a methodological contribution to this literature, by exploring the role of dynamic probits in predicting these events.

Using a comprehensive dataset of systemic banking crises in Europe, we find that equity prices, house prices growth, credit-to-GDP gaps and debt to service ratios are among the most useful indicators in signalling emerging crises.

We show that adding a dynamic component to the multivariate modelling of systemic banking crises substantially improves the models' accuracy. This result holds both in and out of sample. Furthermore, taking into account nonlinearities in the dependent variables around crisis events also improves the quality of early warning tools. These small changes in model estimation may significantly improve policymakers' ability to better meet the challenge of being able to identify an emerging crises, thus allowing them to act in advance. 


\section{References}

Alessi, L., A. Antunes, J. Babeckỳ, S. Baltussen, M. Behn, D. Bonfim, O. Bush, C. Detken, J. Frost, R. Guimarães, T. Havránek, M. Joy, K. Kauko, J. Matějů, N. Monteiro, B. Neudorfer, T. Peltonen, P. M. M. Rodrigues, M. Rusnák, W. Schudel, M. Sigmund, H. Stremmel, K. Šmídková, R. van Tilburg, B. Vašíček, and D. Žigraiová (2014). "A Horse Race of Early Warning Systems Developed by the Macroprudential Research Network." Mimeo, European Central Bank.

Alessi, Lucia and Carsten Detken (2011). "Quasi real time early warning indicators for costly asset price boom/bust cycles: A role for global liquidity." European Journal of Political Economy, 27(3), 520-533.

Babeckỳ, Jan, Tomas Havranek, Jakub Mateju, Marek Rusnák, Katerina Smidkova, and Borek Vasicek (2012). "Banking, debt and currency crises: early warning indicators for developed countries." Working Paper 1485, European Central Bank.

Basel Committee on Banking Supervision (2010). "Guidance for national authorities operating the countercyclical capital buffer."

Beck, Nathaniel, David L. Epstein, Simon Jackman, and Sharyn L. O'Halloran (2001). "Alternative models of dynamics in binary time-series-cross-section models: The example of state failure." URL http://www.nyu.edu/gsas/ dept/politics/faculty/beck/emory.pdf

Berg, Andrew and Rebecca N. Coke (2004). "Autocorrelation-corrected standard errors in panel probits: an application to currency crisis prediction." Working Paper 04/39, International Monetary Fund.

Betz, Frank, Silviu Oprică, Tuomas A. Peltonen, and Peter Sarlin (2014). "Predicting distress in European banks." Journal of Banking and Finance, 45, 225-241.

Bismans, Francis and Reynald Majetti (2013). "Forecasting recessions using financial variables: the French case." Empirical Economics, 44(2), 419-433.

Bonfim, Diana and Nuno Monteiro (2013). "The implementation of the countercyclical capital buffer: rules versus discretion." Banco de Portugal Financial Stability Report, November.

Borio, Claudio and Mathias Drehmann (2009). "Assessing the risk of banking crises-revisited." BIS Quarterly Review, March. 
Borio, Claudio and Philip William Lowe (2002). "Asset prices, financial and monetary stability: exploring the nexus." Working Paper 114, BIS.

Boyd, John H., Gianni De Nicolò, and Elena Loukoianova (2009). "Banking crises and crisis dating: theory and evidence." Working Paper 09/141, IMF.

Burnside, Craig, Martin Eichenbaum, and Sergio Rebelo (2004). "Government guarantees and self-fulfilling speculative attacks." Journal of Economic Theory, 119(1), 31-63.

Bussière, Matthieu and Marcel Fratzscher (2006). "Towards a new early warning system of financial crises." Journal of International Money and Finance, 25(6), 953-973.

Caggiano, Giovanni, Pietro Calice, and Leone Leonida (2014). "Early warning systems and systemic banking crises in low income countries: A multinomial logit approach." Journal of Banking and Finance, 47, 258-269.

Candelon, Bertrand, Elena-Ivona Dumitrescu, and Christophe Hurlin (2012). "How to evaluate an early-warning system: Toward a unified statistical framework for assessing financial crises forecasting methods." IMF Economic Review, 60(1), 75-113.

Candelon, Bertrand, Elena-Ivona Dumitrescu, and Christophe Hurlin (2014). "Currency crisis early warning systems: Why they should be dynamic." International Journal of Forecasting, 30(4), 1016-1029.

Cecchetti, Stephen G., Marion Kohler, and Christian Upper (2009). "Financial crises and economic activity." Working Paper 15379, National Bureau of Economic Research.

Chang, Roberto and Andrès Velasco (2001). "A model of financial crises in emerging markets." Quarterly Journal of Economics, 116(2), 489-517.

Chaudron, Raymond and Jakob De Haan (2014). "Identifying and dating systemic banking crises using incidence and size of bank failures." Working Paper 406, De Nederlandsche Bank.

Chortareas, G., A. Cipollini, and G. Kapetanios (2010). "Forecasting financial distress in emerging markets: a dynamic probit analysis." Mimeo.

Cox, David R., Gudmundur Gudmundsson, Georg Lindgren, Lennart Bondesson, Erik Harsaae, Petter Laake, Katarina Juselius, and Steffen L. Lauritzen (1981). "Statistical analysis of time series: some recent developments." Scandinavian Journal of Statistics, 8(2), 93-115. 
Davis, R. and Tiemen M. Woutersen (2008). "Comparing Early Warning System for Banking Crises." Journal of Financial Stability, 2(4), 89-120.

de Jong, Robert M. and Tiemen Woutersen (2011). "Dynamic time series binary choice." Econometric Theory, 27(4), 673-702.

Demirgüç-Kunt, Asli and Enrica Detragiache (2005). "Cross-country empirical studies of systemic bank distress: a survey." Working Paper 05/96, IMF.

Detken, Carsten, Olaf Weeken, Lucia Alessi, Diana Bonfim, Miguel M. Boucinha, Christian Castro, Sebastian Frontczak, Gaston Giordana, Julia Giese, Nadya Jahn, J. Kakes, B. Klaus, J. H. Lang, N. Puzanova, and P. Welz (2014). "Operationalising the countercyclical capital buffer: indicator selection, threshold identification and calibration options." Occasional paper, European Systemic Risk Board.

Drehmann, Mathias, Claudio Borio, Leonardo Gambacorta, Gabriel Jimenez, and Carlos Trucharte (2010). "Countercyclical capital buffers: exploring options." Working Paper 317, BIS.

Drehmann, Mathias and Mikael Juselius (2014). "Evaluating early warning indicators of banking crises: Satisfying policy requirements." International Journal of Forecasting, 30, 759-780.

Duttagupta, Rupa and Paul Cashin (2011). "Anatomy of banking crises in developing and emerging market economies." Journal of International Money and Finance, 30, 354-376.

Edge, Rochelle M. and Ralf R. Meisenzahl (2011). "The unreliability of creditto-GDP ratio gaps in real-time: Implications for countercyclical capital buffers." International Journal of Central Banking, 7(4), 261-298.

Estrella, Arturo and Gikas A. Hardouvelis (1991). "The term structure as a predictor of real economic activity." Journal of Finance, 46(2), 555-576.

Estrella, Arturo and Frederic S. Mishkin (1998). "Predicting US recessions: Financial variables as leading indicators." Review of Economics and Statistics, 80(1), 45-61.

Estrella, Arturo and Anthony P. Rodrigues (1998). "Consistent covariance matrix estimation in probit models with autocorrelated errors." Staff Report 39, Federal Reserve Bank of New York.

Falcetti, Elisabetta and Merxe Tudela (2006). "Modelling Currency Crises in Emerging Markets: A Dynamic Probit Model with Unobserved Heterogeneity and Autocorrelated Errors." Oxford Bulletin of Economics and Statistics, 
68(4), 445-471.

Frankel, Jeffrey and George Saravelos (2012). "Can leading indicators assess country vulnerability? Evidence from the 2008-09 global financial crisis." Journal of International Economics, 87(2), 216-231.

Gourieroux, Christian S., Alain Monfort, and Alain Trognon (1982). "Estimation and test in probit models with serial correlation." Working Paper Couverture Orange 8220, CEPREMAP.

Jackman, Simon (1998). "Time Series Models for Discrete Data: solutions to a problem with quantitative studies of international conflict." In Annual Meeting of the Society for Political Methodology, San Diego.

Jordà, Òscar, Moritz Schularick, and Alan M. Taylor (2011). "Financial crises, credit booms, and external imbalances: 140 years of lessons." IMF Economic Review, 59(2), 340-378.

Jordà, Òscar, Moritz Schularick, and Alan M. Taylor (2013). "When credit bites back." Journal of Money, Credit and Banking, 45(2), 3-28.

Kaminsky, Graciela L. and Carmen M. Reinhart (1999). "The twin crises: the causes of banking and balance-of-payments problems." American Economic Review, 89(3), 473-500.

Kauko, Karlo (2014). "How to foresee banking crises? A survey of the empirical literature." Economic Systems, 38(3), 289-308.

Kauppi, Heikki and Pentti Saikkonen (2008). "Predicting US recessions with dynamic binary response models." Review of Economics and Statistics, 90(4), $777-791$.

Krugman, Paul (1979). "A model of balance-of-payments crises." Journal of Money, Credit and Banking, 11(3), 311-325.

Laeven, Luc and Fabian Valencia (2012). "Systemic banking crises database: An update." Working Paper 12/163, IMF.

Liang, Kung-Yee and Scott L. Zeger (1986). "Longitudinal data analysis using generalized linear models." Biometrika, 73(1), 13-22.

Nyberg, Henri (2010). "Dynamic probit models and financial variables in recession forecasting." Journal of Forecasting, 29(1-2), 215-230.

Obstfeld, Maurice (1986). "Rational and Self-fulfilling Balance-of-Payments Crises." American Economic Review, 76(1), 72-81.

Oet, Mikhail V., Timothy Bianco, Dieter Gramlich, and Stephen J. Ong (2013). "SAFE: An early warning system for systemic banking risk." Journal of 
Banking and Finance, 37(11), 4510-4533.

Petersen, Mitchell A. (2009). "Estimating standard errors in finance panel data sets: Comparing approaches." Review of Financial Studies, 22(1), 435-480.

Poirier, Dale J. and Paul A. Ruud (1988). "Probit with dependent observations." Review of Economic Studies, 55(4), 593-614.

Reinhart, Carmen M and Kenneth Rogoff (2011). This Time Is Different: Eight Centuries of Financial Folly. Princeton University Press.

Wright, Jonathan H. (2006). "The yield curve and predicting recessions." Finance and Economics Discussion Series 2006-07, Federal Reserve Board. 


\section{FIGURES}

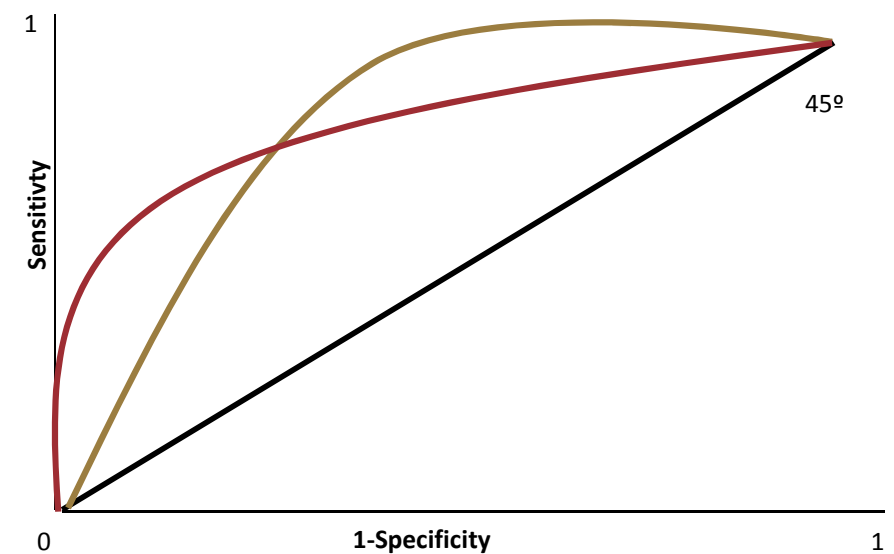

Figure 1: Examples of ROC Curves 


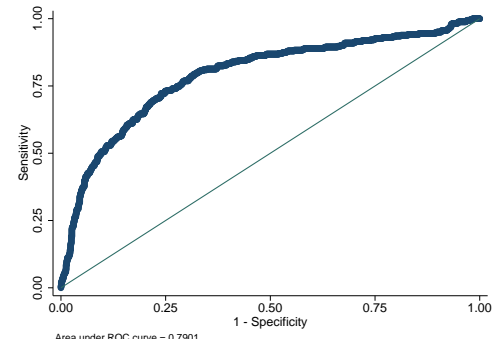

(A) Simple - Total Period

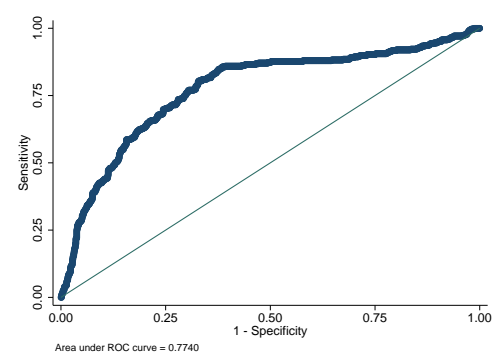

(c) Simple - Early Period

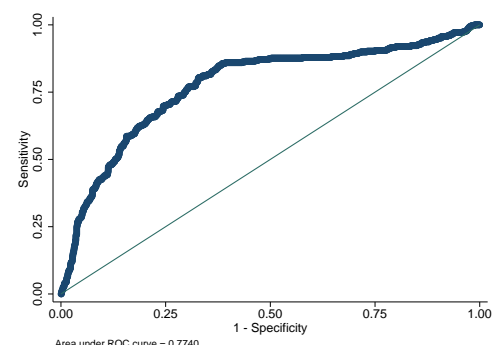

(E) Simple - Late Period

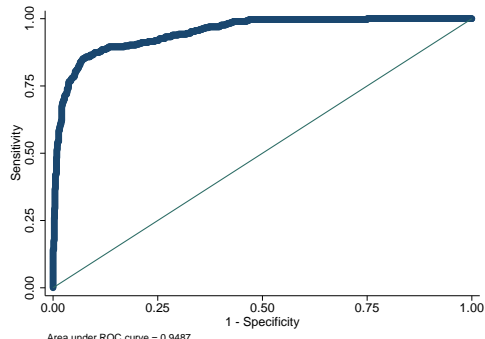

(в) Dynamic - Total Period

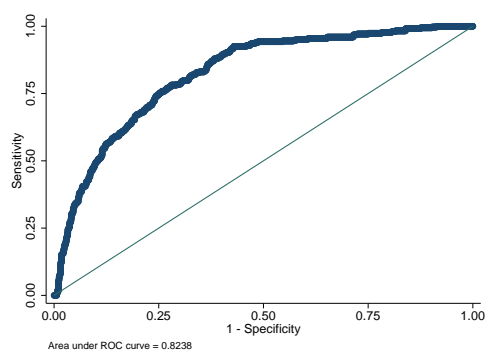

(D) Dynamic - Early Period

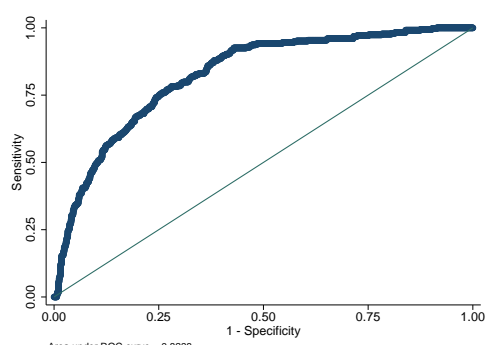

(F) Dynamic - Late Period

Figure 2: Simple and Dynamic Models

Sources: Babecky et al (2012), BIS, ECB, Detken et al. (2014), Eurostat, IMF, OECD, Thomson Reuters, and authors' calculations. 


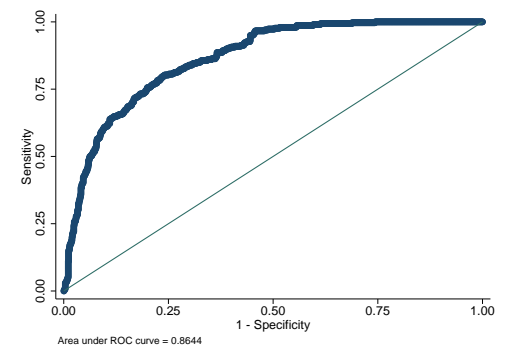

(A) Exuberance - Early Period

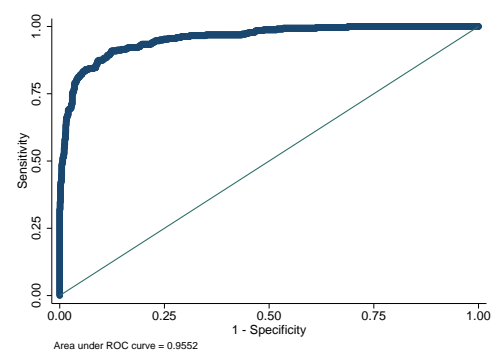

(c) Exuberance - LatePeriod

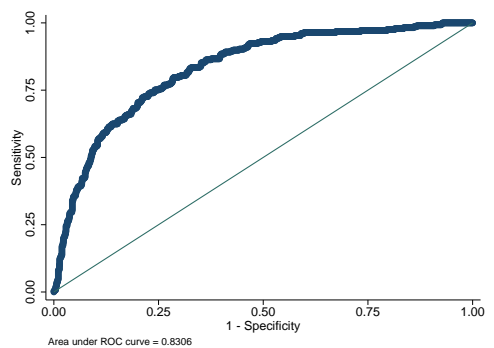

(в) Latent - Early Period

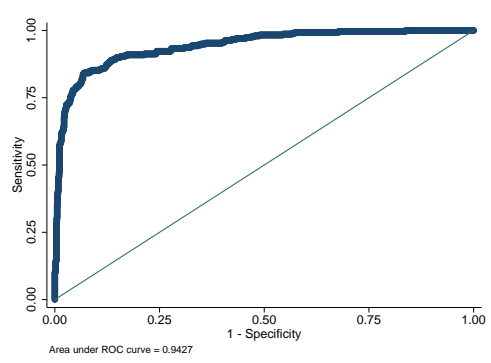

(D) Latent - Late Period

Figure 3: Exuberance and Latent Variable Models

Note: The model with exuberance indicators does not converge when the entire period is considered.

Sources: Babecky et al (2012), BIS, ECB, Detken et al. (2014), Eurostat, IMF, OECD, Thomson Reuters, and authors' calculations. 


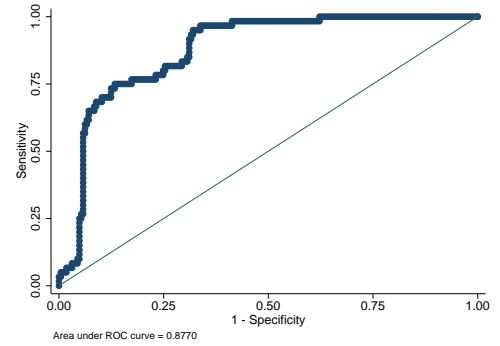

(A) Simple - Total Period

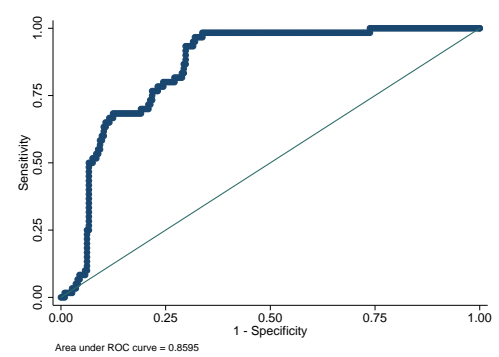

(c) Simple - Early Period

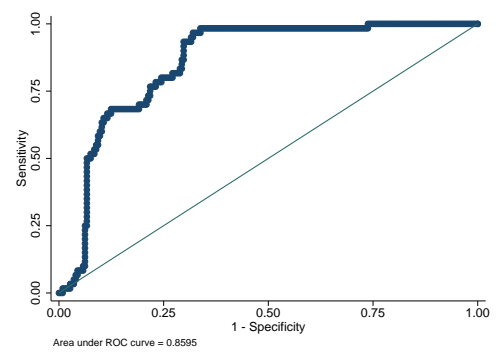

(E) Simple - Late Period

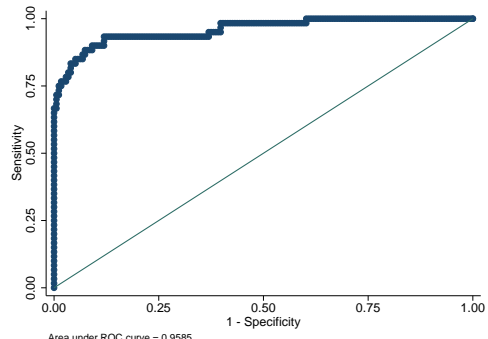

(в) Dynamic - Total Period

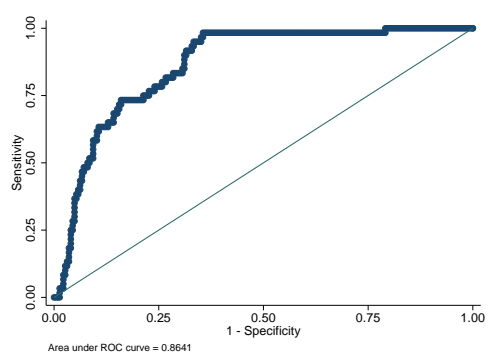

(D) Dynamic - Early Period

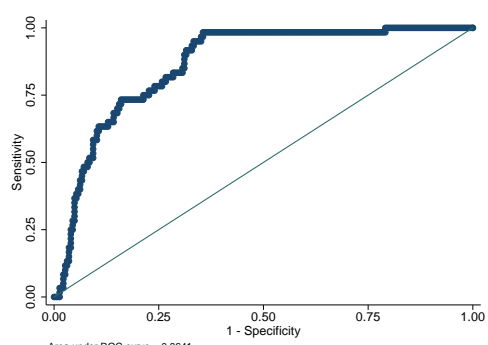

(F) Dynamic - Late Period

Figure 4: Out-of-Sample exercise (Simple and Dynamic Models)

Sources: Babecky et al (2012), BIS, ECB, Detken et al. (2014), Eurostat, IMF, OECD, Thomson Reuters, and authors' calculations. 


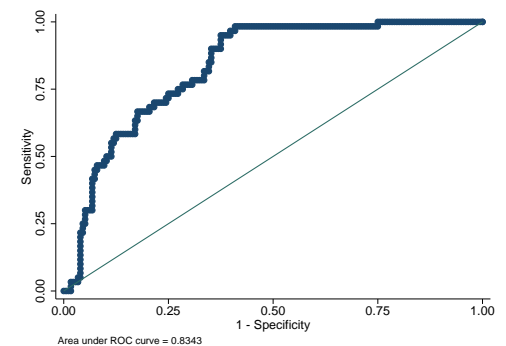

(A) Exuberance - Early Period

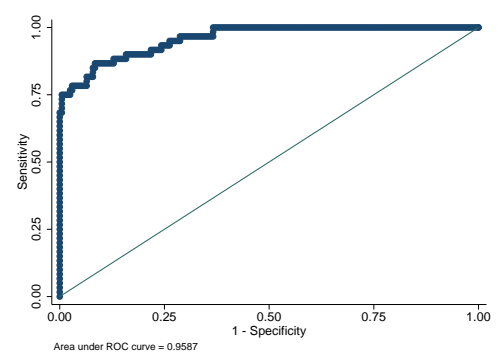

(c) Exuberance - LatePeriod

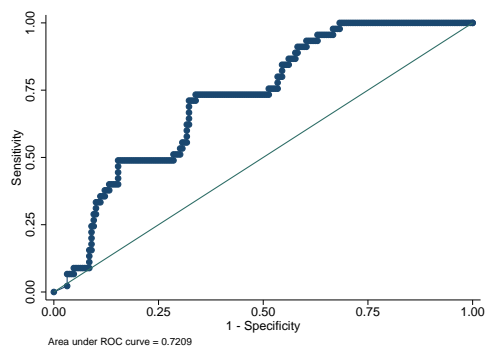

(в) Latent - Early Period

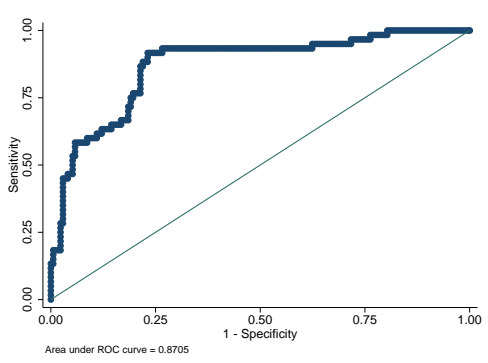

(D) Latent - Late Period

Figure 5: Out-of-Sample exercise (Exuberance and Latent Variable Models)

Note: The model with exuberance indicators does not converge when the entire period is considered.

Sources: Babecky et al (2012), BIS, ECB, Detken et al. (2014), Eurostat, IMF, OECD, Thomson Reuters, and authors' calculations. 


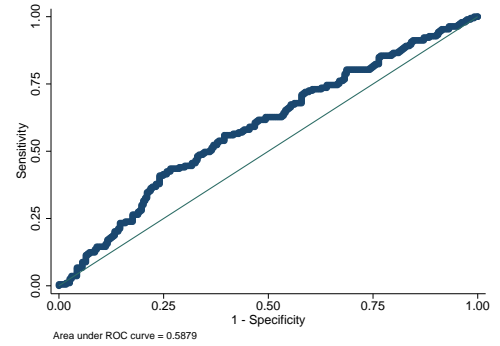

(A) Simple - Total Period

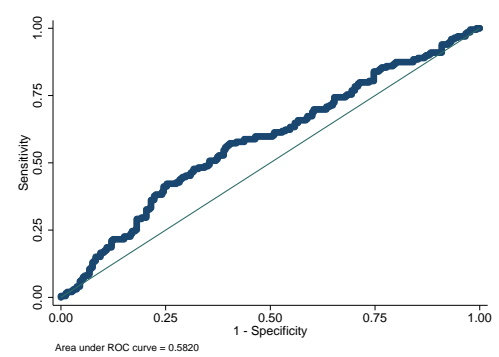

(c) Simple - Early Period

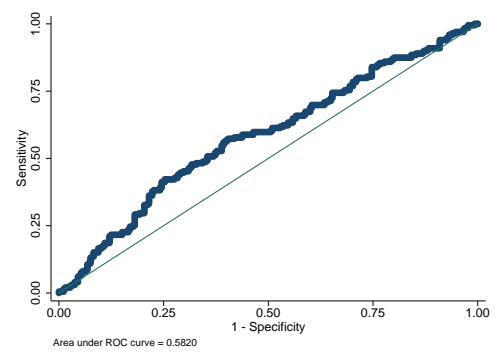

(E) Simple - Late Period

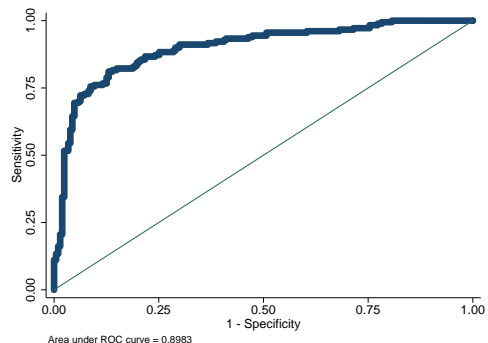

(B) Dynamic - Total Period

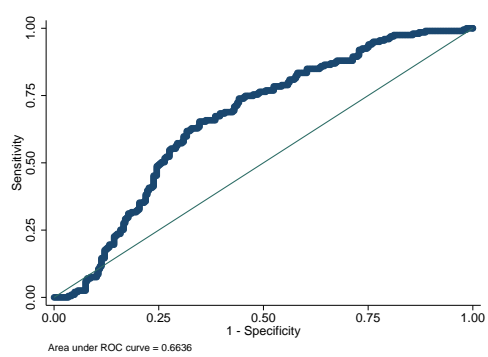

(D) Dynamic - Early Period

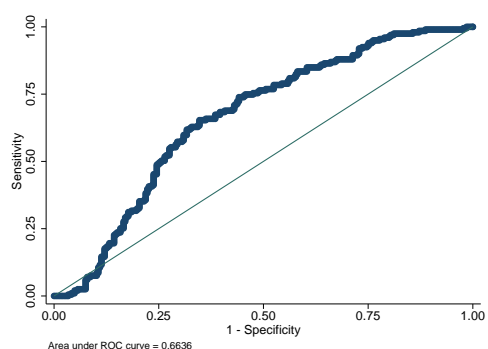

(F) Dynamic - Late Period

Figure 6: Out-of-Time exercise (Simple and Dynamic Models)

Sources: Babecky et al (2012), BIS, ECB, Detken et al. (2014), Eurostat, IMF, OECD, Thomson Reuters, and authors' calculations. 


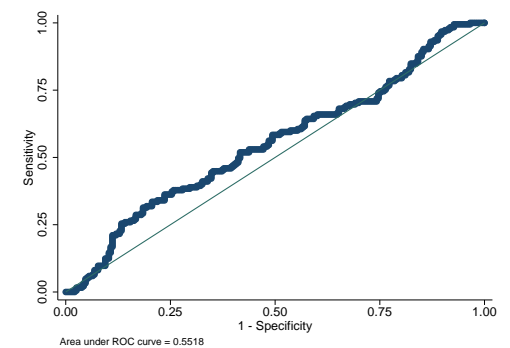

(A) Non-Linearities - Early Period

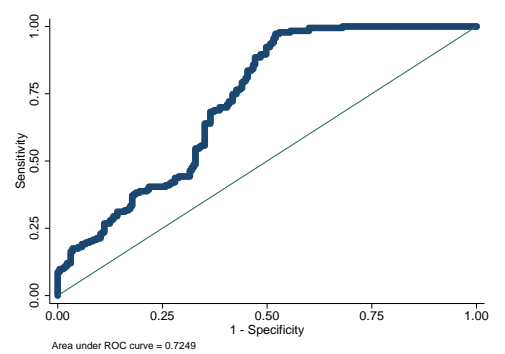

(c) Non-Linearities - LatePeriod

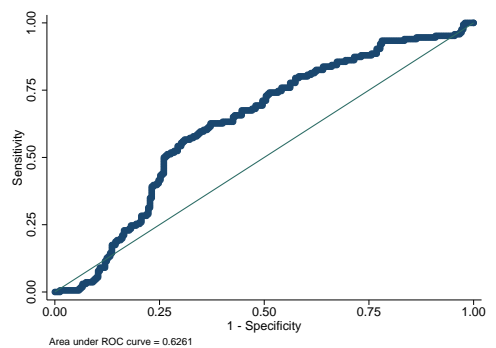

(в) Latent - Total Period

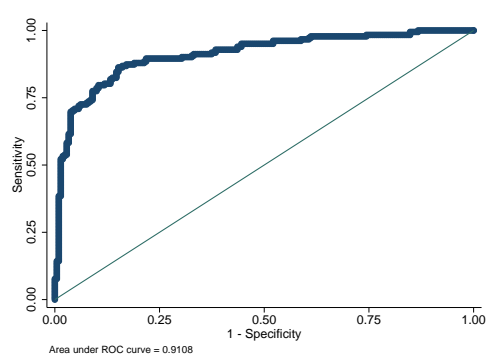

(D) Latent - Late Period

Figure 7: Out-of-Time exercise (Exuberance and Latent Variable Models)

Note: The model with exuberance indicators does not converge when the entire period is considered.

Sources: Babecky et al (2012), BIS, ECB, Detken et al. (2014), Eurostat, IMF, OECD, Thomson Reuters, and authors' calculations. 


\begin{tabular}{|c|c|c|}
\hline Early & Period - 20-12 lags & Late Period - 12-4 lags \\
\hline Lags & $\mathbf{P}>|\mathbf{z}|$ & $\begin{array}{ll}\text { Coef. } & \mathbf{P}>|\mathbf{z}|\end{array}$ \\
\hline
\end{tabular}

Crisis dummy

Equity price index

Debt service ratio

Credit-to-GDP gap

House price index (yoy)

Equity price index (P90)

Credit-to-GDP gap (P50)

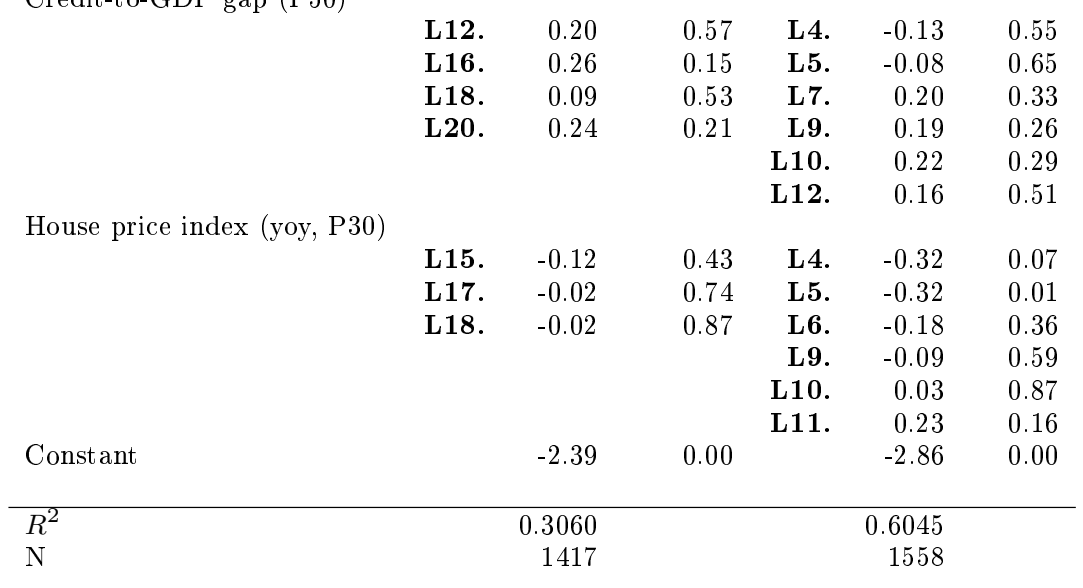

TABLE A1. Table - Regression results: probits with exuberance indicators

Note: all variables defined in Table 1 . The total period refers to lags [20;4], the early period $[20 ; 12]$ and the late period $[12 ; 4]$. Standard errors clustered by country.

Sources: Babecky et al (2012), BIS, ECB, Detken et al. (2014), Eurostat, IMF, OECD, Thomson Reuters, and authors' calculations. 


\begin{tabular}{|c|c|c|c|c|c|}
\hline & d & Early & Period & s: & \\
\hline Las & Coef. & Lags & Coef. & $\mathbf{P}>|\mathbf{z}|$ & Lag \\
\hline
\end{tabular}

Latent Variable (latente1)

Equity price index

Debt service ratio

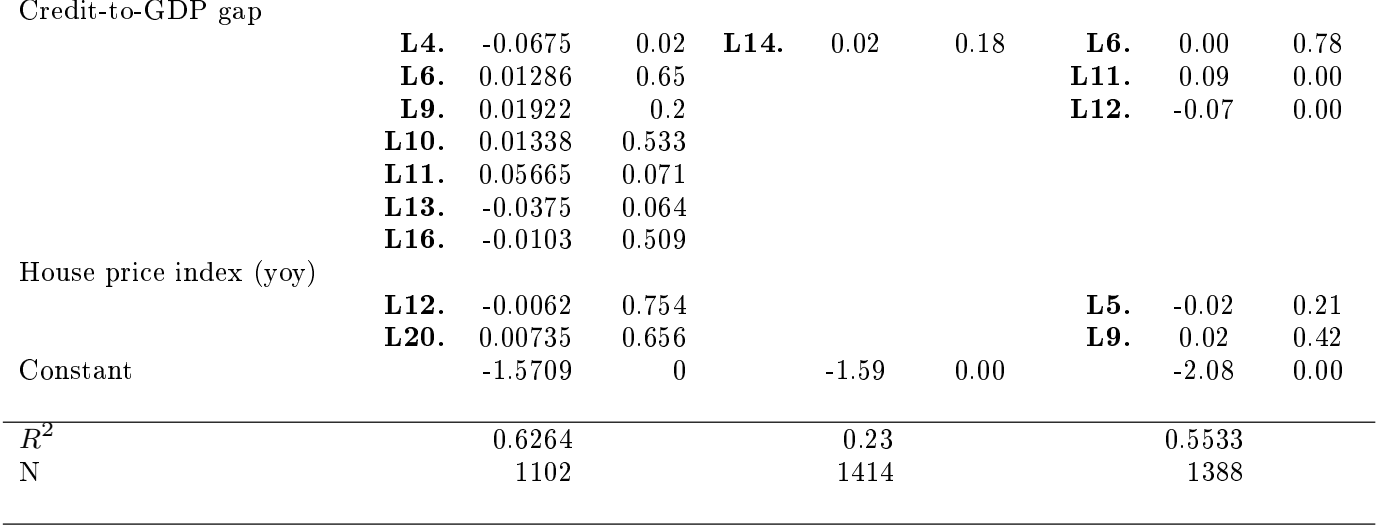

TABLE A2. Regression results: Latent variable

Note: all variables defined in Table 1 . The total period refers to lags [20;4], the early period $[20 ; 12]$ and the late period $[12 ; 4]$. Standard errors clustered by country.

Sources: Babecky et al (2012), BIS, ECB, Detken et al. (2014), Eurostat, IMF, OECD, Thomson Reuters, and authors' calculations.

$\begin{array}{rlccrcc}0.162 & \text { L12. } & -0.16 & 0.00 & \text { L4. } & -0.05 & 0.31 \\ 0.008 & \text { L15. } & 0.07 & 0.05 & \text { L5. } & -0.03 & 0.42 \\ 0.708 & \text { L17. } & 0.18 & 0.03 & \text { L7. } & 0.10 & 0.02 \\ 0.023 & & & & \text { L11. } & 0.05 & 0.25 \\ 0.503 & & & & & & \\ 0.025 & & & & & & \\ & & & & & & \\ 0 & \text { L12. } & 1.47 & 0.00 & \text { L4. } & 7.20 & 0.00 \\ 0 & \text { L15. } & -0.23 & 0.15 & \text { L5. } & -4.12 & 0.00 \\ 0.656 & \text { L17. } & -0.62 & 0.01 & \text { L7. } & -0.03 & 0.94 \\ 0.125 & & & & \text { L11. } & -1.19 & 0.03 \\ 0.071 & & & & & & \\ 0 & & & & & & \\ & & & & & & \\ 0.327 & \text { L12. } & 0.01 & 0.03 & \text { L6. } & 0.01 & 0.04 \\ 0.966 & \text { L13. } & 0.00 & 0.50 & & & \\ 0.836 & \text { L17. } & 0.00 & 0.90 & & & \\ & \text { L19. } & 0.00 & 0.35 & & & \end{array}$

$\begin{array}{lllllll}0 & \text { L12. } & 14.09 & 0.00 & \text { L4. } & 17.62 & 0.00\end{array}$

$\begin{array}{lllllll}0.008 & \text { L14. } & -4.78 & 0.08 & \text { L7. } & -17.72 & 0.00\end{array}$

0.27 L20. $\quad-9.22 \quad 0.00$

$\begin{array}{lrr}\text { L10. } & -6.9766 & 0.212 \\ \text { L14. } & -10.246 & 0.19\end{array}$

L18. $-7.5366 \quad 0.169$

L5. 0.11299

L4. 7.13029

L5. -4.1274

L9. 0.00446

L11. 0.00014
L7. $\quad-5.6671$
Credit-to-GDP gap 


\section{WORKING PAPERS}

\section{3}

01|13 Macroeconomic forecasting using lowfrequency filters

João Valle e Azevedo | Ana Pereira

02|13 Everything you always wanted to know about sex discrimination

Ana Rute Cardoso | Paulo Guimarães | Pedro Portugal

03|13 Is there a role for domestic demand pressure on export performance?

Paulo Soares Esteves | António Rua

04|13 Ageing and fiscal sustainability in a small euro area economy

Gabriela Castro | José R. Maria | Ricardo Mourinho Félix | Cláudia Rodrigues Braz

05|13 Mind the gap! The relative wages of immigrants in the Portuguese labour market Sónia Cabral | Cláudia Duarte

06|13 Foreign direct investment and institutional reform: Evidence and an application to Portugal

Paulo Júlio | Ricardo Pinheiro-Alves | José Tavares

07|13 Monetary policy shocks: We got news! Sandra Gomes | Nikolay Iskrev | Caterina Mendicino

08|13 Competition in the Portuguese Economy: Estimated price-cost margins under imperfect labour markets

João Amador | Ana Cristina Soares

09|13 The sources of wage variation: a threeway high-dimensional fixed effects regression model

Sonia Torres | Pedro Portugal | John T. Addison | Paulo Guimarães
10|13 The output effects of (non-separable) government consumption at the zero lower bound

Valerio Ercolani | João Valle e Azevedo

11|13 Fiscal multipliers in a small euro area economy: How big can they get in crisis times?

Gabriela Castro | Ricardo M. Felix | Paulo Julio | Jose R. Maria

12|13 Survey evidence on price and wage rigidities in Portugal

Fernando Martins

13|13 Characterizing economic growth paths based on new structural change tests Nuno Sobreira | Luis C. Nunes | Paulo M. M. Rodrigues

14|13 Catastrophic job destruction Anabela Carneiro | Pedro Portugal | José Varejão

$15 \mid 13$ Output effects of a measure of tax shocks based on changes in legislation for Portugal

Manuel Coutinho Pereira | Lara Wemans

16|13 Inside PESSOA - A detailed description of the model

Vanda Almeida | Gabriela Castro | Ricardo M. Félix | Paulo Júlio | José R. Maria

17|13 Macroprudential regulation and macroeconomic activity

Sudipto Karmakar

18|13 Bank capital and lending: An analysis of commercial banks in the United States Sudipto Karmakar | Junghwan Mok 


\section{4}

1|14 Autoregressive augmentation of MIDAS regressions

Cláudia Duarte

2|14 The risk-taking channel of monetary policy - exploring all avenues

Diana Bonfim | Carla Soares

3|14 Global value chains: Surveying drivers, measures and impacts

João Amador | Sónia Cabral

4|14 Has US household deleveraging ended? a model-based estimate of equilibrium debt

Bruno Albuquerque | Ursel Baumann | Georgi Krustev

5|14 The weather effect: estimating the effect of voter turnout on electoral outcomes in italy

Alessandro Sforza

6|14 Persistence in the banking industry: fractional integration and breaks in memory Uwe Hassler | Paulo M.M. Rodrigues | Antonio Rubia

7|14 Financial integration and the great leveraging Daniel Carvalho

8|14 Euro area structural reforms in times of a global crisis

Sandra Gomes

9|14 Labour demand research: towards a better match between better theory and better data

John T. Addison | Pedro Portugal | José Varejão
10|14 Capital inflows and euro area long-term interest rates

Daniel Carvalho | Michael Fidora

11|14 Misallocation and productivity in the lead up to the Eurozone crisis

Daniel A. Dias | Carlos Robalo Marquesz | Christine Richmond

12|14 Global value chains: a view from the euro area

João Amador | Rita Cappariello | Robert Stehrer

13|14 A dynamic quantitative macroeconomic model of bank runs

Elena Mattana | Ettore Panetti

14|14 Fiscal devaluation in the euro area: a model-based analysis

S. Gomes | P. Jacquinot | M. Pisani

15|14 Exports and domestic demand pressure: a dynamic panel data model for the euro area countries

Elena Bobeica | Paulo Soares Esteves | António Rua | Karsten Staehr

16|14 Real-time nowcasting the US output gap: singular spectrum analysis at work Miguel de Carvalho | António Rua 
1|15 Unpleasant debt dynamics: can fiscal consolidations raise debt ratios?

Gabriela Castro | Ricardo M. Félix | Paulo Júlio | José R. Maria

2|15 Macroeconomic forecasting starting from survey nowcasts

João Valle e Azevedo | Inês Gonçalves

3|15 Capital regulation in a macroeconomic model with three layers of default

Laurent Clerc | Alexis Derviz | Caterina Mendicino | Stephane Moyen | Kalin Nikolov | Livio Stracca | Javier Suarez | Alexandros P. Vardoulakis

4|15 Expectation-driven cycles: time-varying effects

Antonello D'Agostino | Caterina Mendicino

5|15 Seriously strengthening the tax-benefit link

Pedro Portugal | Pedro S. Raposo

6|15 Unions and collective bargaining in the wake of the great recession

John T. Addison | Pedro Portugal | Hugo Vilares

7|15 Covariate-augmented unit root tests with mixed-frequency data

Cláudia Duarte

8|15 Financial fragmentation shocks

Gabriela Castro | José R. Maria | Paulo úlio | Ricardo M. Félix

9|15 Central bank interventions, demand for collateral, and sovereign borrowing cost Luís Fonseca | Matteo Crosignani | Miguel Faria-e-Castro
10|15 Income smoothing mechanisms after labor market transitions

Nuno Alves | Carlos Martins

11|15 Decomposing the wage losses of displaced workers: the role of the reallocation of workers into firms and job titles Anabela Carneiro | Pedro Raposo | Pedro Portugal

12|15 Sources of the union wage gap: results from high-dimensional fixed effects regression models

John T. Addison | Pedro Portugal | Hugo Vilares

13|15 Assessing european firms' exports and productivity distributions: the compnet trade module Antoine Berthou | Emmanuel Dhyne | Matteo Bugamelli | Ana-Maria Cazacu | Calin-Vlad Demian | Peter Harasztosi | Tibor Lalinsky | Jaanika Meriküll | Filippo Oropallo | Ana Cristina Soares

14|15 A new regression-based tail index estimator: an application to exchange rates

João Nicolau | Paulo M. M. Rodrigues

15|15 The effect of bank shocks on firm-level and aggregate investment João Amador | Arne J. Nagengast

16|15 Networks of value added trade João Amador | Sónia Cabral

17|15 House prices: bubbles, exuberance or something else? Evidence from euro area countries Rita Fradique Lourenço | Paulo M. M. Rodrigues 


\section{6}

1|16 A mixed frequency approach to forecast private consumption with ATM/POS data

Cláudia Duarte | Paulo M. M. Rodrigues | António Rua

2|16 Monetary developments and expansionary fiscal consolidations: evidence from the EMU

António Afonso | Luís Martins

3|16 Output and unemployment, Portugal, 2008-2012

José R. Maria

4|16 Productivity and organization in portuguese firms

Lorenzo Caliendo | Luca David Opromolla | Giordano Mion | Esteban Rossi-Hansberg

5|16 Residual-augmented IVX predictive regression

Matei Demetrescu | Paulo M. M. Rodrigues

6|16 Understanding the public sector pay gap Maria M. Campos | Evangelia Papapetrou | Domenico Depalo Javier J. Pérez | Roberto Ramos

7|16 Sorry, we're closed: loan conditions when bank branches close and firms transfer to another bank

Diana Bonfim | Gil Nogueira | Steven Ongena

8|16 The effect of quantitative easing on lending conditions

Laura Blattner | Luísa Farinha | Gil Nogueira
9|16 Market integration and the persistence of electricity prices

João Pedro Pereira | Vasco Pesquita | Paulo M. M. Rodrigues | António Rua

10|16 EAGLE-FLI | A macroeconomic model of banking and financial interdependence in the euro area

N. Bokan | A. Gerali | S. Gomes | P. Jacquinot M. Pisani

11|16 Temporary contracts' transitions: the role of training and institutions

Sara Serra

12|16 A wavelet-based multivariate multiscale approach for forecasting António Rua

13|16 Forecasting banking crises with dynamic panel probit models António Antunes | Diana Bonfim | Nuno Monteiro | Paulo M. M. Rodrigues 


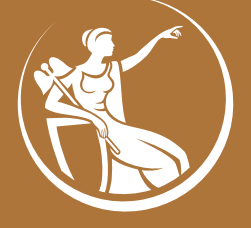

